\title{
Effects of bio-chemo-mechanical processes on the properties of contaminated marine sediments
}

\author{
FRANCESCA SOLLECITO*, MICHAEL PLÖTZE $\dagger$, ALEXANDER M. PUZRIN $\ddagger$, CLAUDIA VITONE§, \\ DANIELA MICCOLI $\|$ and FEDERICA COTECCHIA $\|$
}

\begin{abstract}
A detailed multi-scale investigation of the geotechnical, chemical and mineralogical properties was conducted on contaminated sediment samples collected within the Mar Piccolo, a marine basin in the south of Italy. The basin is located close to one of the most important industrial sites in Europe, which has also been declared 'at high risk of environmental crisis' and prioritised for remediation activities. A multidisciplinary investigation campaign showed that the samples collected close to the sea floor are characterised by high values of both heavy metals and organic pollutants and by the presence of significant amount of organic matter. Several samples in the top layer exhibited peculiar geotechnical properties, in terms of plasticity and activity indexes, compressibility and hydraulic permeability. While the prime suspect for such unconventional behaviour was chemo-mechanical coupling between the soil skeleton and contaminants, it turned out that the biogeochemical degradation of organic matter and the presence of microfossils and diatoms is likely to affect significantly the micro to macro behaviour of polluted marine sediments.
\end{abstract}

KEYWORDS: contaminated material; environmental engineering; laboratory tests

\section{INTRODUCTION}

The research presented in this paper has been prompted by the emblematic case of the contaminated Mar Piccolo (MP) basin in Taranto (southern Italy, Fig. 1), where the high degree of pollution that has been recorded in the clayey sediments at the sea bottom (Cardellicchio et al., 2007; Petronio et al., 2012), affects the water quality (ARPA, 2014) and promotes bio-accumulation of pollutants in fish and mussels (Giandomenico et al., 2016). The site has been recently subjected to a governmental investigation campaign (Sollecito et al., 2019a; Vitone et al., 2020; Cotecchia et al., 2021), to define sustainable remediation actions for environmental risk mitigation (Todaro et al., 2021).

Geotechnical characterisation of the clayey sediments has shown that the physical and mechanical properties of the recent MP sediments do not vary solely with the composition

Manuscript received 7 May 2021; revised manuscript accepted 20 August 2021.

Discussion on this paper is welcomed by the editor.

Published with permission by the ICE under the CC-BY 4.0 license. (http://creativecommons.org/licenses/by/4.0/)

* Department of Civil, Environmental, Land, Building Engineering and Chemistry, Politecnico di Bari, Bari, Italy (Orcid:0000-0002-4699-5248).

$\dagger$ Department of Civil, Environmental and Geomatic Engineering. ETH Zürich - Institute for Geotechnical Engineering, Zurich, Switzerland (Orcid:0000-0001-9833-4196).

t Department of Civil, Environmental and Geomatic Engineering. ETH Zürich - Institute for Geotechnical Engineering, Zurich, Switzerland (Orcid:0000-0002-9566-8841).

$\S$ Department of Civil, Environmental, Land, Building Engineering and Chemistry, Politecnico di Bari, Bari, Italy

(Orcid:0000-0001-6529-4167).

|| Department of Civil, Environmental, Land, Building Engineering and Chemistry, Politecnico di Bari, Bari, Italy.

q Department of Civil, Environmental, Land, Building Engineering and Chemistry, Politecnico di Bari, Bari, Italy

(Orcid:0000-0001-9846-4193). of the soil skeleton and the soil deposition-loading history, as expected for uncontaminated recent sediments. This finding has inspired the present study, which has been finalised to interpret the bio-chemical sources of the discrepancies between values of geotechnical properties of part of the MP sediments and the values that would be expected according to traditional relations between such properties and the soil composition and history. Accounting for the bio-chemical effects discussed in this paper is relevant to the design of the remedial measures required to mitigate the risk in contaminated systems such as the MP basin.

The effects of chemo-mechanical coupling in soils are usually interpreted according to the Gouy-Chapman diffusive double layer (DDL) theory (Gouy, 1910; Chapman, 1913). According to this theory, the thickness of the DDL in clays decreases when either the pore water ion concentration or the cation valence increase and the dielectric constant decreases, as for clays embodying high concentrations of salts, metal ions and organic pollutants. These conditions favour clay particle flocculation and prompt significant variations of the soil index properties and mechanical parameter values, with respect to those characterising the clay when the pore water is pure (e.g. Sridharan \& Ventakappa Rao, 1973; Di Maio, 1996; Santamarina et al., 2002; Sridharan, 2002; Calvello et al., 2005; Kaya \& Fang, 2005; Mitchell \& Soga, 2005; Spagnoli et al., 2011; Goodarzi et al., 2016; Jang \& Santamarina, 2016).

Most contributions to the literature checking the validity of the DDL theory deal with monomineralic clays, mixed either with a saturated solution, or with a single organic fluid. Conversely, the MP sediments are formed by a pool of minerals and contain pore water of marine salinity, which may contain, in combination, organic matter $(\mathrm{OM})$, diatoms and fossils, heavy metals and organic pollutants. The anthropogenic pollutants have been found in concentrations often higher than the thresholds according to environmental law, but lower than those used in the literature for spiking tests on the monomineralic clays. Therefore, an original new investigation has been necessary to assess the effects of the 


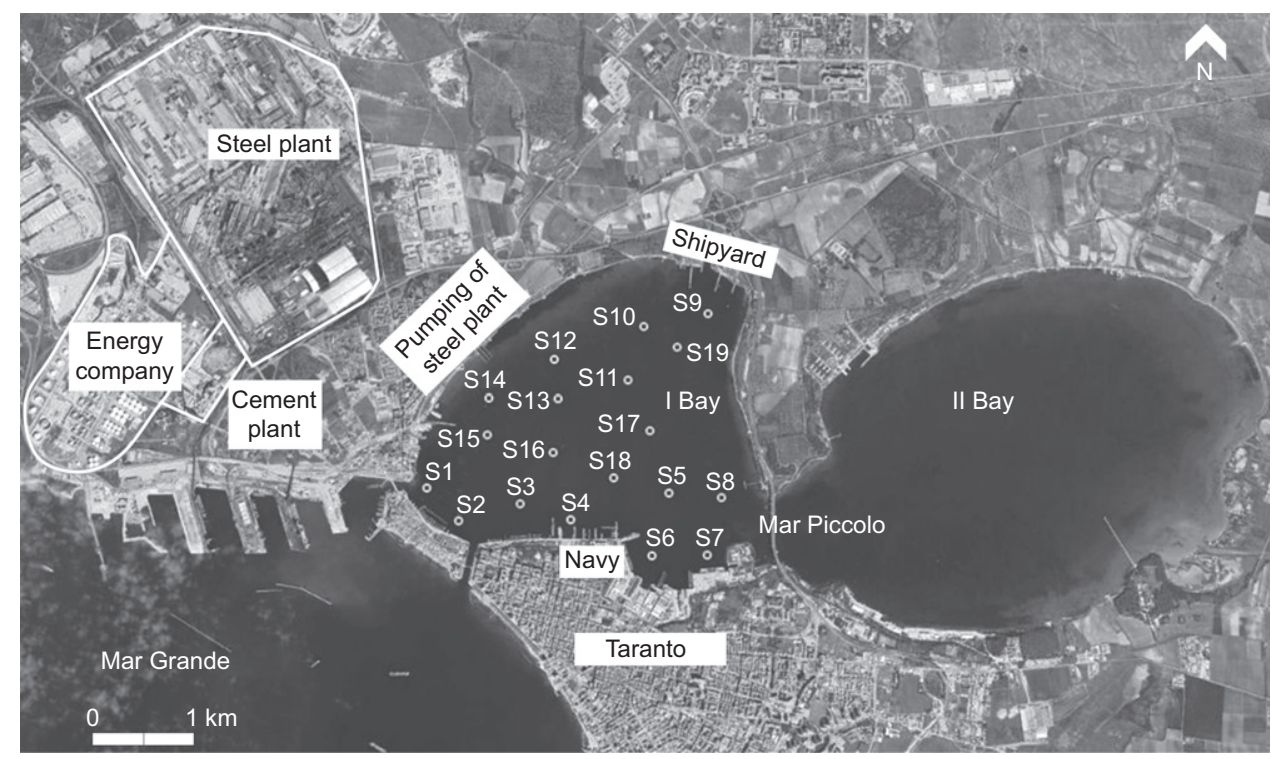

Fig. 1. The Mar Piccolo (MP) basin (Taranto, southern Italy): location of the 19 sampling sites (S-sites) of the investigation campaign (see Cotecchia et al., 2021)

bio-chemo-mechanical coupled processes that may act in the MP sediments and affect their geotechnical properties.

Owing to its capability to adsorb water and promote the formation of a more open fabric, OM influences the geotechnical properties of clays (e.g. Rashid \& Brown, 1975; Booth \& Dahl, 1986; Husein Malkawi et al., 1999; Paul \& Barras, 1999; Mitchell \& Soga, 2005; Levesque et al., 2007). The effect of OM on soil properties depends largely on whether the organic matter is decomposed or not (Bennett et al., 1985; Varghese et al., 2019). For example, during the process of OM degradation, the colonies of microorganisms determining OM oxidation tend to promote 'binding' of the particles to form aggregates (Bhaskar \& Bhosle, 2005; Colreavy et al., 2019). The sealing of the outer surface of these aggregates has even been recognised as an effect of the activity of either natural microorganisms (Mitchell \& Santamarina, 2005) or artificial polyamines (Zumsteg et al., 2013). In contrast, the presence of microfossils and diatoms, of high intra-skeletal void space, can provide an apparent increase of the soil plasticity and activity indexes, as well as the soil compressibility, irrespective of the clay fraction size and nature (Diaz-Rodriguez et al., 1998; Tanaka \& Locat, 1999; Tanaka, 2003; Lee et al., 2011; Caicedo et al., 2018).

In this paper, a multi-scale experimental investigation has been designed to characterise the $\mathrm{OM}$, the microfossils and the pollutants present in the MP sediments, and to check their effects on the behaviour of these sediments. The multi-scale data give evidence of the extent to which the bio-chemical processes in real soils may influence their index properties and mechanical parameters, supporting the appropriate engineering characterisations of sediments located in complex ecosystems and the selection of the parameter values to be input in the design of remediation measures, when the sediment pollution is a source of environmental risk.

\section{GEOTECHNICAL INVESTIGATION OF THE MACRO-BEHAVIOUR OF SEDIMENTS \\ Sediment sampling}

The MP (Fig. 1) is a semi-enclosed marine basin with two bays of lagoon features, of total surface area about $20.72 \mathrm{~km}^{2}$ and maximum water depth of $13 \mathrm{~m}$. The sediments are part of a Late Pleistocene to Holocene deposit, overlying the local geological formation of the sub-Apennine clays (ASP, hereafter), which represents the parent formation of most of the sediments deposited in the bays (see Cotecchia et al. (2021) for the geological setting and history of the basin).

Since the early decades of the last century, the waste of local industrial activities (e.g. shipyards, navy, steel and cement plants as shown in Fig. 1), together with chemical compounds coming from the surrounding cultivated lands and from uncontrolled sewage discharge pipes, have caused pollution of the basin, as reported in several studies (Cardellicchio et al., 2007; Petronio et al., 2012; ARPA, 2014; Kralj et al., 2016; Cotecchia et al., 2021). It has been shown that the top sediments (by $5 \mathrm{~m}$ depth) are contaminated by heavy metals (e.g. arsenic (As), lead $(\mathrm{Pb})$, cadmium $(\mathrm{Cd})$, mercury $(\mathrm{Hg})$, copper $(\mathrm{Cu})$ and zinc $(\mathrm{Zn}))$, asbestos and organic pollutants (polycyclic aromatic hydrocarbons (PAHs), chlorinated solvents, polychlorinated biphenyls (PCBs) and dioxins).

Sediment samples were retrieved down 19 boreholes drilled in the I Bay (S-sites in Fig. 1), from 0 to $39 \mathrm{~m}$ below the sea floor (bsf), in order to characterise the whole MP system (Adamo et al., 2018; Cotecchia et al., 2021). Most of the samples were taken in the Late Pleistocene and Holocene (recent) formation, with the exception of two samples taken in the ASP. Either Shelby or Denison tube piston samplers were used within the stiffer sediment strata, while soft sediments were generally sampled by means of an Osterberg hydraulic piston sampler and a thin-walled polycarbonate tube sampler. The latter was manually pushed by scuba divers into the top layer of ultra-soft sediments, 0-1.5 m bsf (Sollecito et al., 2019b). As reported in Table 1, the samples included in this paper come from a shallow stratum (i.e. down to $1.5 \mathrm{~m}$ bsf, letter ' $\mathrm{S}$ ' after the borehole number), an intermediate one (depth interval $1.5-3.0 \mathrm{~m}$ bsf, letter ' $\mathrm{I}$ '), a deep one (depth interval 3.0-39.0 m bsf, letter ' $\mathrm{D}$ ') and the ASP.

Details about the procedures used in the multi-scale testing are reported in the online supplementary material.

\section{Physical properties}

Figure 2 shows the grading envelopes for the different depth intervals of the MP deposit which the samples here of 
Table 1. Composition and plasticity properties of the MP samples included in the present paper, collected at different depths in the shallow (-S), intermediate (-I), deep (-D) layers and in the sub-Apennine clay (ASP) from the sites in Fig. 1

\begin{tabular}{|c|c|c|c|c|c|c|c|c|c|c|}
\hline Sample (site-layer) & Average depth: $\mathrm{m}$ bsf & $\mathrm{SF}: \%$ & $\mathrm{MF}: \%$ & $\mathrm{CF}: \%$ & $\gamma: \mathrm{kN} / \mathrm{m}^{3}$ & $e_{0}$ & $w_{\mathrm{L}}: \%$ & PI: $\%$ & $A$ & LI \\
\hline S6-S & $0 \cdot 5$ & $9 \cdot 0$ & $47 \cdot 3$ & $43 \cdot 7$ & $15 \cdot 14$ & $2 \cdot 298$ & $80 \cdot 8$ & $50 \cdot 1$ & $1 \cdot 15$ & $1 \cdot 22$ \\
\hline S6-I & $2 \cdot 25$ & $9 \cdot 5$ & $47 \cdot 0$ & $43 \cdot 5$ & $15 \cdot 41$ & 1.926 & $65 \cdot 0$ & $36 \cdot 8$ & $0 \cdot 85$ & $1 \cdot 19$ \\
\hline S6-D & 6 & $15 \cdot 3$ & $58 \cdot 6$ & $26 \cdot 1$ & $16 \cdot 40$ & $1 \cdot 543$ & $42 \cdot 3$ & $20 \cdot 5$ & $0 \cdot 79$ & $1 \cdot 77$ \\
\hline S7-S & 0.5 & $7 \cdot 0$ & $41 \cdot 3$ & $51 \cdot 7$ & $14 \cdot 36$ & $2 \cdot 255$ & $78 \cdot 2$ & $46 \cdot 5$ & 0.90 & $1 \cdot 13$ \\
\hline S7-I & $2 \cdot 25$ & $3 \cdot 3$ & $49 \cdot 7$ & $47 \cdot 0$ & $15 \cdot 58$ & $1 \cdot 893$ & $69 \cdot 9$ & $41 \cdot 7$ & 0.89 & 1.09 \\
\hline S7-ASP & $14 \cdot 25$ & $3 \cdot 2$ & $47 \cdot 3$ & $49 \cdot 5$ & $19 \cdot 64$ & $0 \cdot 741$ & $53 \cdot 5$ & $29 \cdot 0$ & 0.59 & $0 \cdot 10$ \\
\hline S8-S & 0.5 & $7 \cdot 6$ & $53 \cdot 3$ & $39 \cdot 1$ & $15 \cdot 99$ & $2 \cdot 273$ & $73 \cdot 3$ & $43 \cdot 3$ & $1 \cdot 11$ & 1.90 \\
\hline S9-S & 0.5 & $4 \cdot 0$ & $39 \cdot 0$ & $57 \cdot 0$ & $13 \cdot 97$ & $3 \cdot 094$ & $61 \cdot 8$ & $34 \cdot 0$ & 0.60 & $2 \cdot 57$ \\
\hline S12-S & $0 \cdot 5$ & $26 \cdot 3$ & $43 \cdot 5$ & $30 \cdot 2$ & $13 \cdot 15$ & $4 \cdot 190$ & $113 \cdot 8$ & $69 \cdot 6$ & $2 \cdot 30$ & $1 \cdot 59$ \\
\hline S17-S & $0 \cdot 5$ & $4 \cdot 2$ & $30 \cdot 4$ & $65 \cdot 4$ & $14 \cdot 04$ & $3 \cdot 165$ & $95 \cdot 4$ & $56 \cdot 7$ & $0 \cdot 87$ & $1 \cdot 43$ \\
\hline Spiked sample & $10 \cdot 55$ & $3 \cdot 4$ & $49 \cdot 0$ & $47 \cdot 6$ & $16 \cdot 7$ & $1 \cdot 550$ & $64 \cdot 5$ & $35 \cdot 6$ & $0 \cdot 75$ & $0 \cdot 79$ \\
\hline
\end{tabular}

Note: SF, sand fraction; MF, silt fraction; $\mathrm{CF}$, clay fraction; $\gamma$, bulk unit weight; $e_{0}$, initial void ratio; $w_{\mathrm{L}}$, liquid limit; PI, plasticity index; $A$, activity index; LI, liquidity index.

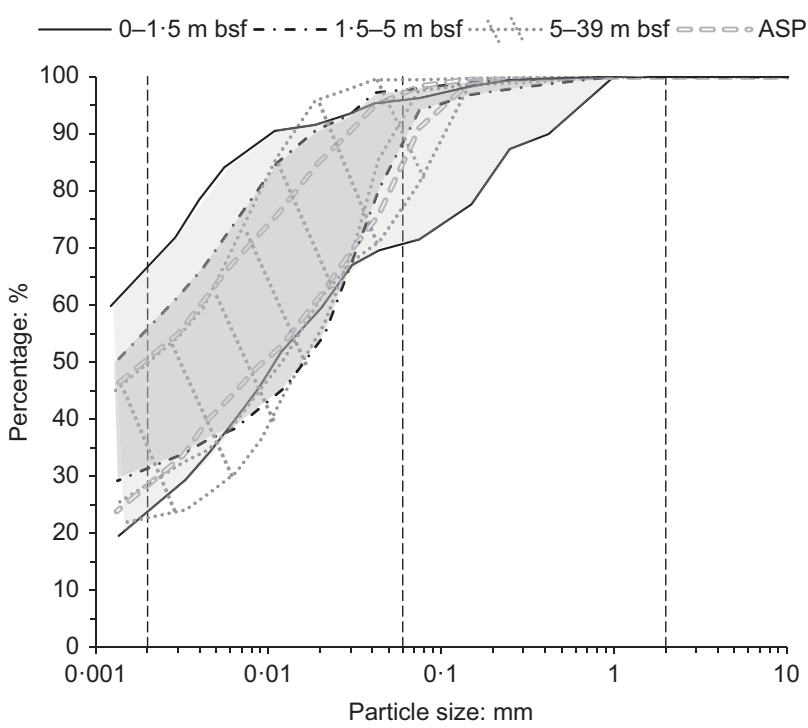

Fig. 2. Grading envelopes of the Mar Piccolo (MP) sediments (ASP, sub-Apennine clays)

reference belong to. The sediments are mostly fine-grained soils, whose clay fraction $(\mathrm{CF})$ varies between $22 \cdot 5$ and $65 \cdot 4 \%$, sand fraction (SF) between 0.5 and $29 \cdot 4 \%$, and silt fraction (MF) from $30 \cdot 5$ to $69 \cdot 5 \%$ (Fig. 2; ASTM D422 (ASTM, 2007); section S1 in the online supplementary material). In particular, as shown in Table 1, the samples under study are clays with silt, or silts with clay, from sandy to slightly sandy.

Despite the limited variability in grading, the samples are characterised by a large variability of both the plasticity index (PI; ASTM D4318 (ASTM, 2017) and ASTM D4542 (ASTM, 2000); Imai et al., 1978; section S1 in the online supplementary material) and the activity index ( $A$; Table 1 and Fig. 3). In particular, the shallow samples (circles in Fig. 3) are characterised by the highest variability of both PI (from 34.0 to $78.8 \%$ ) and $A$ (from 0.60 to $2 \cdot 49$ ), and by the highest values of both these indexes. The samples selected for this study (labelled in Fig. 3) represent the overall variability of the soil properties across the deposit (Table 1). Specifically, sample S12-S is that of the highest activity index and lies at the upper bound of the PI-CF data range in Fig. 3. In contrast, S9-S sample represents the lower bound of the data range in the figure. The other samples, from larger depths, are of high to very high plasticity and of low to high activity (Table 1).

\section{Mechanical properties}

The one-dimensional compression behaviour of the sediment samples under study (ASTM D2435 (ASTM, 2011); section $\mathrm{S} 1$ in the online supplementary material) is reported in the void ratio, $e$, against vertical effective stress, $\sigma_{\mathrm{v}}^{\prime}$, plot in Fig. 4. The curves show that both the initial void ratio $\left(e_{0}\right)$ and the compression index $\left(C_{\mathrm{C}}\right)$ decrease significantly with the sampling depth. The variability in $e_{0}$ and $C_{\mathrm{C}}$ is particularly relevant for the shallow samples.

The results in Fig. 4 show that, despite being geologically normally consolidated (overconsolidation ratio, OCR = $\left.\sigma_{\mathrm{vc}}^{\prime} / \sigma_{\mathrm{v} 0}^{\prime}=1\right)$, some samples have a yield stress ratio (YSR $=\sigma_{\mathrm{vy}}^{\prime} / \sigma_{\mathrm{v} 0}^{\prime}$; Burland, 1990) higher than one. This is probably due to the unloading upon sampling (e.g. for S6-S, S7-S and S9-S, of YSR about 2.5), except for the S12-S sample, of YSR $=8$ and highest compressibility beyond $\sigma_{\mathrm{vy}}^{\prime}(12 \mathrm{kPa})$, which is probably an effect of its peculiar microstructural features, as discussed later. $C_{\mathrm{C}}$ reduces from 1.23 to 0.57 in the shallow layer, and to 0.33 at depth and in the ASP.

The coefficient of permeability $(k)$ has been deduced from the oedometer tests, according to the one-dimensional consolidation theory (Terzaghi, 1923). The $k$ values during loading are plotted against void ratio in Fig. 5. For the shallow layer, the coefficient of permeability at the initial void ratio $\left(k_{e_{0}}\right)$ ranges between $2.08 \times 10^{-10}$ and $6.23 \times 10^{-9} \mathrm{~m} / \mathrm{s}$, (S7-S and S12-S samples, respectively). It reduces to about $1 \times 10^{-9} \mathrm{~m} / \mathrm{s}$ in the intermediate layer and to $1.84 \times 10^{-1} 0 \mathrm{~m} / \mathrm{s}$ in the ASP. The $\log k-e$ curves follow a more or less linear relation, in accordance with Taylor (1948). In particular, the permeability index $\left(C_{k}\right)$ reduces with depth from $1 \cdot 0$ (shallow layer) to $0 \cdot 28$ (ASP). Among the shallow samples, S12-S and S9-S are characterised by the highest and lowest $k$ and $C_{k}$ values, respectively (Fig. 5).

\section{AN INSIGHT INTO THE MINERALOGICAL AND CHEMICAL PROPERTIES OF THE SEDIMENTS Mineralogical properties}

The mineralogical composition of the samples here of reference, measured by means of the X-ray diffraction method (Bish \& Plötze, 2011; Döbelin \& Kleeberg, 2015; section $\mathrm{S} 2 \cdot 1$ in the online supplementary material), is reported in Table 2 . The specimens possess a significant content of carbonate minerals (CM - the sum of calcite, aragonite and dolomite), in the range $28 \cdot 5-46 \mathrm{wt} \%$. Among the clay minerals, smectite $(\mathrm{Sm})$ is prevalent $(9-27 \mathrm{wt} \%)$, followed by mica (i.e. muscovite $7-12 \mathrm{wt} \%$ ), kaolinite $(3 \cdot 2-5 \cdot 2 \mathrm{wt} \%)$ and chlorite $(2 \cdot 7-3 \cdot 9 \mathrm{wt} \%)$. Halite is also present because of the marine environment and it is 


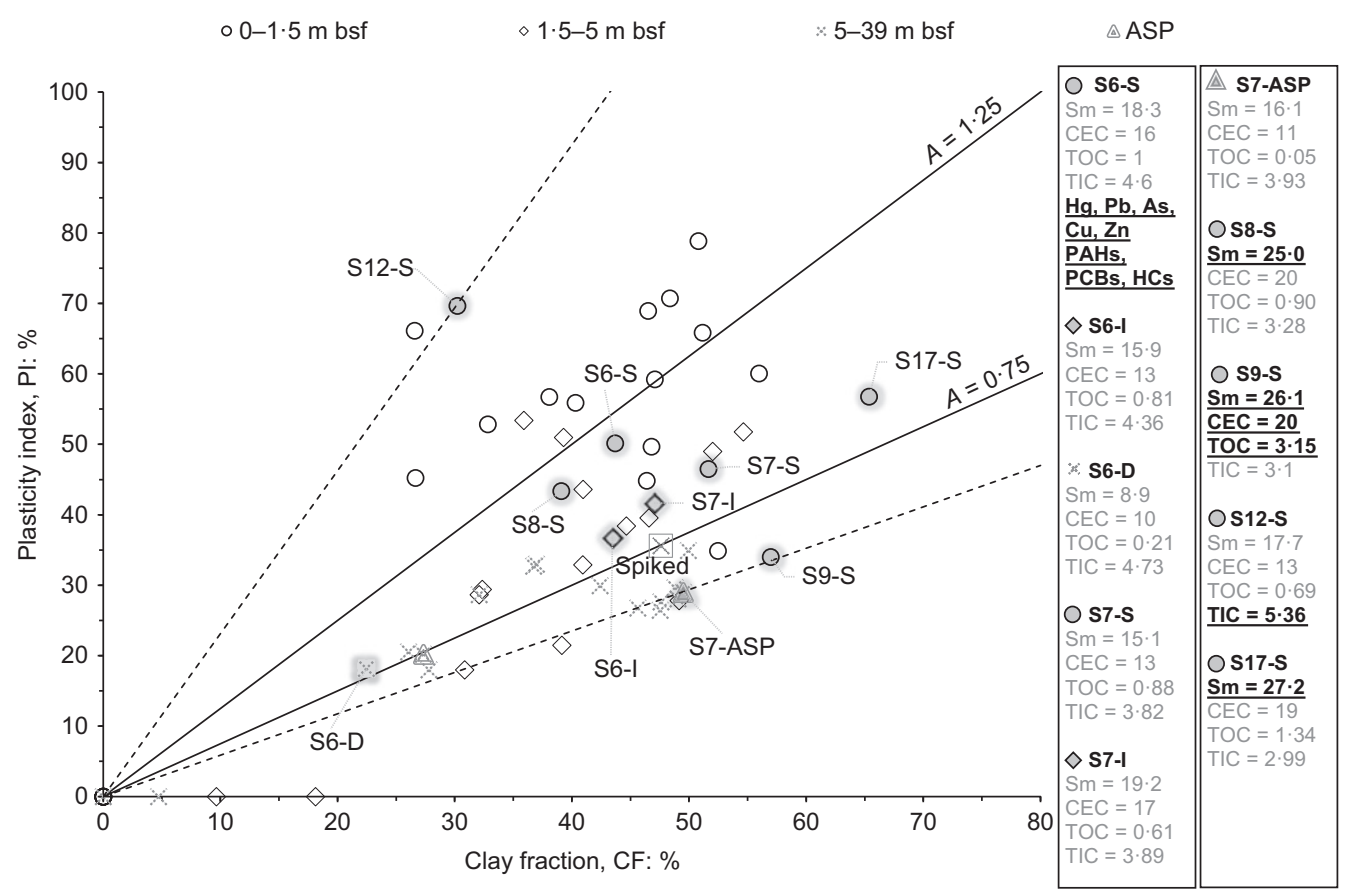

Fig. 3. Activity chart of the Mar Piccolo (MP) sediments which includes the mineralogical and chemical features of the samples selected for the multi-scale investigation. Note: Sm, smectite (\%); CEC, cation exchange capacity (meq/100 g); TOC, total organic carbon (\%); TIC, total inorganic carbon $(\%)$; mercury $(\mathrm{Hg})$, lead $(\mathrm{Pb})$, arsenic $(\mathrm{As})$, copper $(\mathrm{Cu})$, zinc $(\mathrm{Zn})$ metals; polycyclic aromatic hydrocarbons $(\mathrm{PAHs})$, polychlorinated biphenyls (PCBs), hydrocarbons (HCs) are organic pollutants. The highest values are reported in bold font and underlined

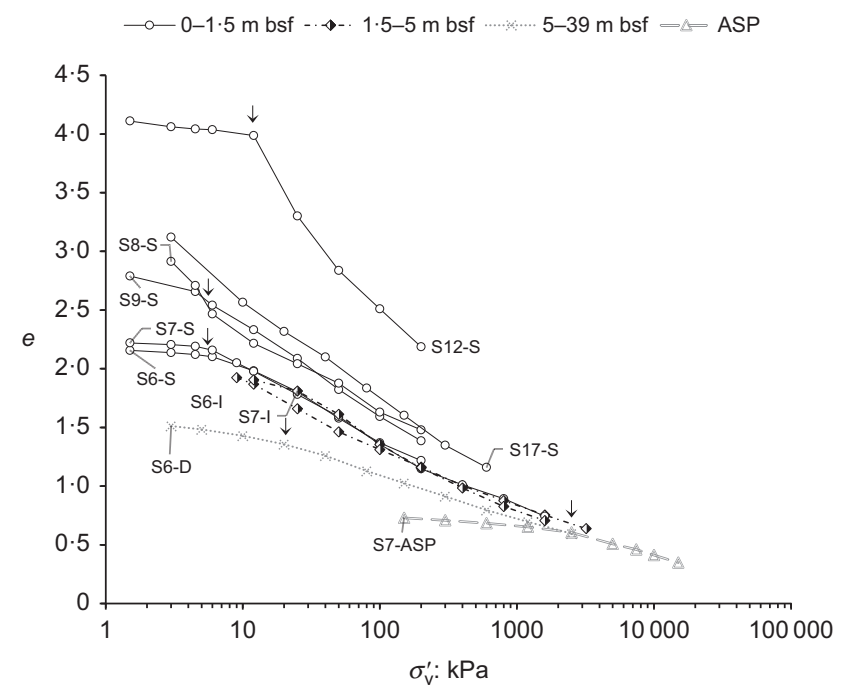

Fig. 4. Oedometer compression curves of the Mar Piccolo (MP) sediments. The arrow is for the yield vertical effective stress, $\sigma_{\mathrm{vy}}^{\prime}$

abundant in the shallow samples. Pyrite has been found in the sediment matrix, especially in the shallow samples, and it is probably the product of the OM mineralisation under anoxic conditions.

The mineralogical profiles in Fig. 6(a) provide evidence of a low variability of mineralogy with depth, allowing the ASP to be recognised as the parent material of the sediments in the whole deposit. Smectite content is highest in only three shallow samples: S17-S, S9-S, S8-S, where Sm is equal to $25-27 \mathrm{wt} \%$.

The cation exchange capacity (CEC; Meier \& Kahr, 1999, section S2.1 in the online supplementary material) of the soil samples varies within a small range (10-20 meq/100 g; Fig. 6(b)), according to the smectite content. The exchangeable cations (section $\mathrm{S} 2 \cdot 1$ in the online supplementary

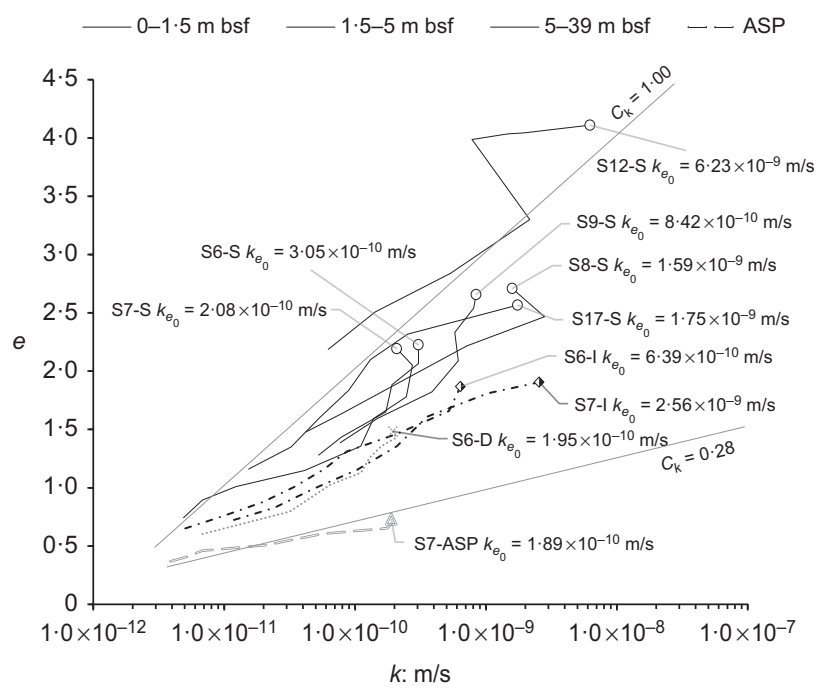

Fig. 5. Coefficient of permeability of the Mar Piccolo (MP) sediments measured during the oedometer loading stages

material) measured in the samples are those typical of marine environments, with sodium being the most abundant one $(8 \cdot 3-15 \cdot 7 \mathrm{meq} / 100 \mathrm{~g})$, followed by magnesium, potassium and calcium. Non-exchangeable ions of heavy metals have been detected in the tested samples.

\section{Chemical properties of the MP samples and effects of spiking tests}

Among the samples here of reference, S6-S is the most polluted one, since it contains the highest concentrations of metals (US Environmental Protection Agency (EPA) method 3052 (EPA, 1996)) and organic pollutants (EPA method 8270D (EPA, 1998; CEN, 2004, 2016): $\mathrm{Hg}: \quad 15 \cdot 36 \mathrm{mg} / \mathrm{kg}, \mathrm{Pb}: 229 \cdot 29 \mathrm{mg} / \mathrm{kg}$, As: $44 \cdot 75 \mathrm{mg} / \mathrm{kg}$, 
Table 2. Mineralogical composition of the bulk sample, cation exchange capacity (CEC) and total organic carbon (TOC) of MP sediments, from shallow (-S), intermediate (-I), deep (-D) and sub-Apennine clay (ASP) layers

\begin{tabular}{|c|c|c|c|c|c|c|c|c|c|c|c|c|c|}
\hline $\begin{array}{l}\text { Sample } \\
\text { (site-layer) }\end{array}$ & $\begin{array}{l}\text { Depth: } \\
\text { m bsf }\end{array}$ & $\begin{array}{l}\text { CM: } \\
\mathrm{wt}^{0} \%\end{array}$ & $\begin{array}{l}\text { Qtz: } \\
\mathrm{wt}^{0} \%\end{array}$ & $\begin{array}{l}\mathrm{Sm}: \\
\mathrm{wt}^{0} \%\end{array}$ & $\begin{array}{l}\text { Mi: } \\
\mathrm{wt}^{0} \%\end{array}$ & $\begin{array}{l}\text { Kao: } \\
\mathrm{wt}^{\circ} \%\end{array}$ & $\begin{array}{l}\text { Chl: } \\
\mathrm{wt}^{0} \%\end{array}$ & $\begin{array}{l}\text { Feld: } \\
\mathrm{wt}^{0} \%\end{array}$ & $\begin{array}{l}\text { Hal: } \\
\mathrm{wt}^{0} \%\end{array}$ & $\begin{array}{l}\text { Pyr: } \\
\mathrm{wt}^{0} \%\end{array}$ & $\begin{array}{c}\text { Others: } \\
\text { wt } \%\end{array}$ & $\begin{array}{c}\text { CEC: } \\
\text { meq/100g }\end{array}$ & TOC: $\%$ \\
\hline S6-S & $0 \cdot 5$ & $42 \cdot 9$ & $10 \cdot 5$ & $18 \cdot 3$ & $9 \cdot 9$ & $4 \cdot 1$ & $3 \cdot 0$ & $6 \cdot 1$ & $3 \cdot 1$ & $1 \cdot 5$ & 0.6 & $16 \cdot 0$ & $1 \cdot 00$ \\
\hline S6-I & $2 \cdot 25$ & $43 \cdot 1$ & $12 \cdot 1$ & $15 \cdot 9$ & $9 \cdot 8$ & $3 \cdot 9$ & $3 \cdot 3$ & $7 \cdot 0$ & $2 \cdot 0$ & $1 \cdot 8$ & $1 \cdot 1$ & $13 \cdot 0$ & $0 \cdot 81$ \\
\hline S6-D & 6 & $41 \cdot 9$ & $20 \cdot 3$ & 8.9 & $7 \cdot 4$ & $3 \cdot 2$ & $3 \cdot 5$ & $11 \cdot 3$ & $1 \cdot 1$ & $1 \cdot 3$ & $1 \cdot 1$ & $10 \cdot 0$ & $0 \cdot 21$ \\
\hline S7-S & $0 \cdot 5$ & $41 \cdot 8$ & $12 \cdot 2$ & $15 \cdot 1$ & $10 \cdot 3$ & $4 \cdot 7$ & $2 \cdot 9$ & $7 \cdot 3$ & $2 \cdot 1$ & $2 \cdot 0$ & $1 \cdot 6$ & $13 \cdot 0$ & $0 \cdot 88$ \\
\hline S7-I & $2 \cdot 25$ & $36 \cdot 6$ & $12 \cdot 6$ & $19 \cdot 2$ & $11 \cdot 2$ & $4 \cdot 6$ & $3 \cdot 6$ & $7 \cdot 2$ & $1 \cdot 7$ & $2 \cdot 2$ & $1 \cdot 1$ & $17 \cdot 0$ & $0 \cdot 61$ \\
\hline S7-ASP & $14 \cdot 25$ & $33 \cdot 4$ & $18 \cdot 6$ & $16 \cdot 1$ & $11 \cdot 6$ & $4 \cdot 3$ & $3 \cdot 9$ & $10 \cdot 0$ & $0 \cdot 7$ & $0 \cdot 4$ & $1 \cdot 0$ & $11 \cdot 0$ & $0 \cdot 05$ \\
\hline S8-S & 0.5 & $33 \cdot 4$ & $9 \cdot 6$ & $25 \cdot 0$ & $11 \cdot 6$ & $5 \cdot 0$ & $3 \cdot 6$ & $5 \cdot 8$ & $2 \cdot 6$ & $2 \cdot 0$ & $1 \cdot 4$ & $20 \cdot 0$ & $0 \cdot 90$ \\
\hline S9-S & $0 \cdot 5$ & $28 \cdot 5$ & $9 \cdot 4$ & $26 \cdot 1$ & $11 \cdot 0$ & $5 \cdot 2$ & $3 \cdot 1$ & $7 \cdot 0$ & $5 \cdot 0$ & $2 \cdot 7$ & $2 \cdot 0$ & $20 \cdot 0$ & $3 \cdot 15$ \\
\hline S12-S & $0 \cdot 5$ & $46 \cdot 1$ & $9 \cdot 1$ & $17 \cdot 7$ & $9 \cdot 2$ & $4 \cdot 2$ & $2 \cdot 7$ & $6 \cdot 1$ & $3 \cdot 0$ & $1 \cdot 3$ & 0.6 & $13 \cdot 0$ & 0.69 \\
\hline S17-S & $0 \cdot 5$ & $29 \cdot 6$ & $10 \cdot 2$ & $27 \cdot 2$ & $12 \cdot 0$ & $5 \cdot 2$ & 3.6 & $6 \cdot 1$ & $2 \cdot 2$ & $2 \cdot 4$ & $1 \cdot 5$ & $19 \cdot 0$ & $1 \cdot 34$ \\
\hline
\end{tabular}

Key: CM, carbonate minerals; Qtz, quartz; Sm, smectite; Mi, mica group; Kao, kaolinite; Chl, chlorite; Feld, feldspars; Hal, halite; Pyr, pyrite; others - anatase, rutile, gypsum.

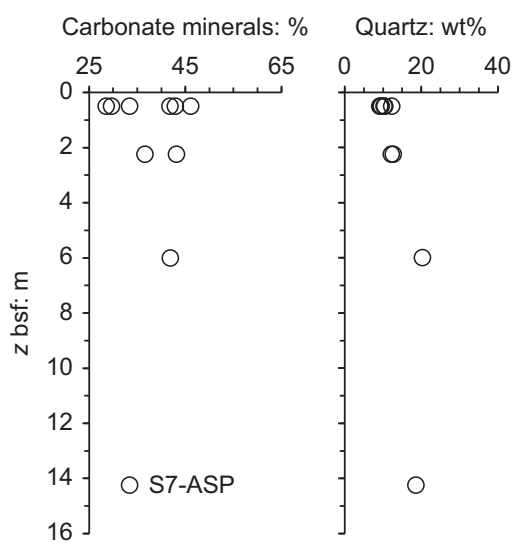

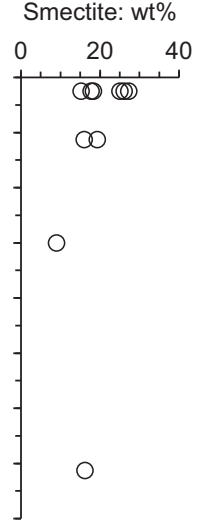

(a)
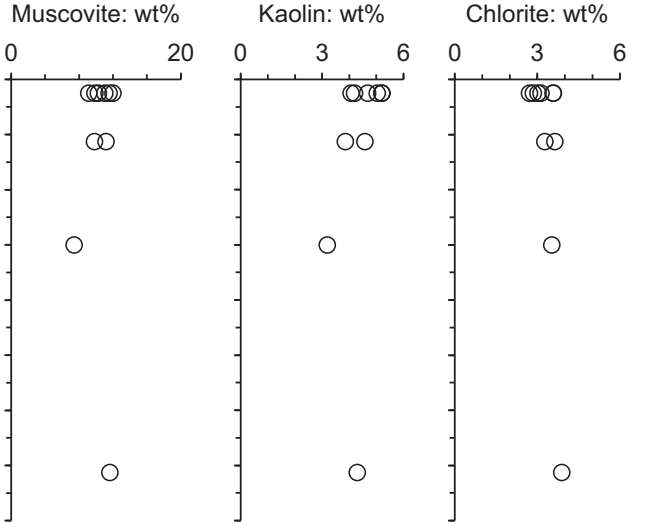

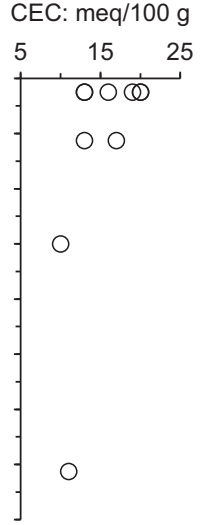

(b)

Fig. 6. Vertical profiles of (a) the main mineralogical fractions determined by X-ray diffraction and (b) cation exchange capacity (CEC)

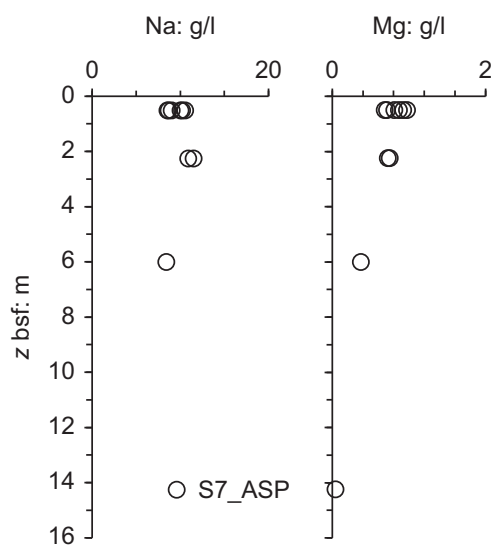

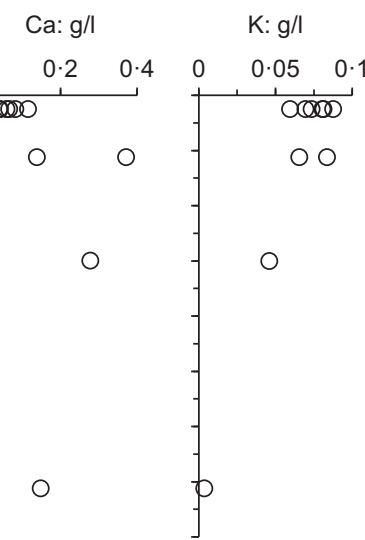

(a)
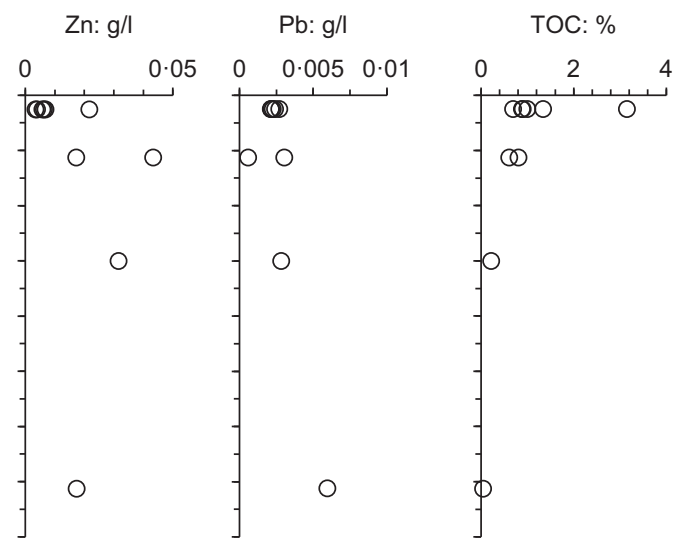

(b)

Fig. 7. Natural contaminants in the basin: (a) major pore fluid constituents (Na, sodium; $\mathrm{Mg}$, magnesium; Ca, calcium; $\mathrm{K}$, potassium; $\mathrm{Zn}$, zinc; $\mathrm{Pb}$, lead). (b) Profile of total organic carbon (TOC) with depth

$\mathrm{Cu}: 83.75 \mathrm{mg} / \mathrm{kg}, \mathrm{Zn}: 403 \mathrm{mg} / \mathrm{kg}, \mathrm{Cr}: 82.85 \mathrm{mg} / \mathrm{kg}$, PAHs: $4772 \mu \mathrm{g} / \mathrm{kg}, \quad$ PCBs: $6829 \mu \mathrm{g} / \mathrm{kg}$, hydrocarbons (HCs): $1634 \mathrm{mg} / \mathrm{kg}$ (Cotecchia et al., 2021). The heavy metal concentrations in the other samples under study are similar to those found in ASP (S7-ASP Pb: $14 \mathrm{mg} / \mathrm{kg}$, As: $11 \mathrm{mg} / \mathrm{kg}$, $\mathrm{Cu}: 8 \mathrm{mg} / \mathrm{kg}$, Zn: $73 \mathrm{mg} / \mathrm{kg}, \mathrm{Cr}: 99 \mathrm{mg} / \mathrm{kg}$ ), which represents the natural site background for the different element concentrations. Organic pollutants such as PCBs, PAHs and HCs are mostly anthropogenic and, therefore, they are absent in the ASP and present in negligible concentrations in all the other samples under study.

The results of the eluate tests (Fig. 7(a)) carried out on all the samples to measure the concentration of metals in the pore fluid (section $\mathrm{S} 2 \cdot 1$ in the online supplementary material) show that the type and the amount of elements in the pore fluid are those typical of seawater (Degens, 1965): sodium (Na) (9-11.5 g/l), magnesium $(\mathrm{Mg})(1 \mathrm{~g} / \mathrm{l})$, calcium $(\mathrm{Ca})$ $(<0 \cdot 4 \mathrm{~g} / \mathrm{l})$ and potassium $(\mathrm{K})(<0 \cdot 1 \mathrm{~g} / \mathrm{l})$, including only a 
very low concentration of zinc and lead and negligible amounts of the other metals (As, $\mathrm{Cu}$ ). This is also the case for the contaminated S6-S sample. No contaminant is released through washing with ethanol.

Differently from the pore fluid salinity, the amount of OM, measured by total organic carbon (TOC; DIN EN 15936 (DIN, 2012); section S2.1 in the online supplementary material), varies greatly in the shallow samples and tends to decrease with depth down to the ASP (TOC $=0.05 \%$; Fig. 7(b)). Specifically, in the shallow layer, TOC is in the range $0 \cdot 69-1 \cdot 4 \%$, except for $\mathrm{S} 9-\mathrm{S}$, which is characterised by the highest TOC value, equal to $3 \cdot 15 \%$ (Table 2 ).

An unpolluted typical MP sediment sample of clayey silt of medium plasticity and high activity (spiked sample in Table 1, Fig. 3) was mixed with two PCB and PAH congeners and subjected to liquid limit $\left(w_{\mathrm{L}}\right)$ measurements (BSI, 1990), in order to investigate the effect of the organic pollutants on the soil plasticity. Each mixture was prepared by adding a solution of pollutants to the sample. The most abundant congeners of PCBs and PAHs found in the MP site, PCB 153 and fluoranthene, were added in concentrations equal to the highest ones measured in situ (well above the Italian environmental thresholds: ICRAM (2004) and Italian Republic (2006)) - that is $\mathrm{PCB}=6829 \mu \mathrm{g} / \mathrm{kg}$ and $\mathrm{PAH}=$ $44707 \mu \mathrm{g} / \mathrm{kg}$ by dry weight. The concentration of PAH was also increased up to 20 times the highest in situ value.

The $w_{\mathrm{L}}$ was determined after 2 and 14 days of curing time. The test results, plotted in Fig. 8, indicate that the $w_{\mathrm{L}}$ values of the spiked samples are similar to that of the unpolluted sample, irrespective of the curing time, the pollution degree and the combination of contaminants. The data show that, for the MP sediments, the index properties are not affected by the presence of organic pollutants in concentrations similar to the in situ ones, even if they exceed the environmental law thresholds. Differently from the findings reported in several publications concerning the effect of chemical spiking on monomineralic clays (kaolin and smectite; e.g. Santamarina et al., 2002; Sridharan, 2002; Spagnoli et al., 2011; Goodarzi et al., 2016), the results presented here show that the concentrations of organic pollutants above the law thresholds may not change the plasticity and the activity indexes of sediments. Other tests from the literature (Muththalib \& Baudet, 2019) report similar results for ASP samples artificially mixed with single heavy metal ions: either $\mathrm{Cu}$, or $\mathrm{Pb}$, or $\mathrm{Zn}$, in concentrations even higher than those found in the S6-S sample.

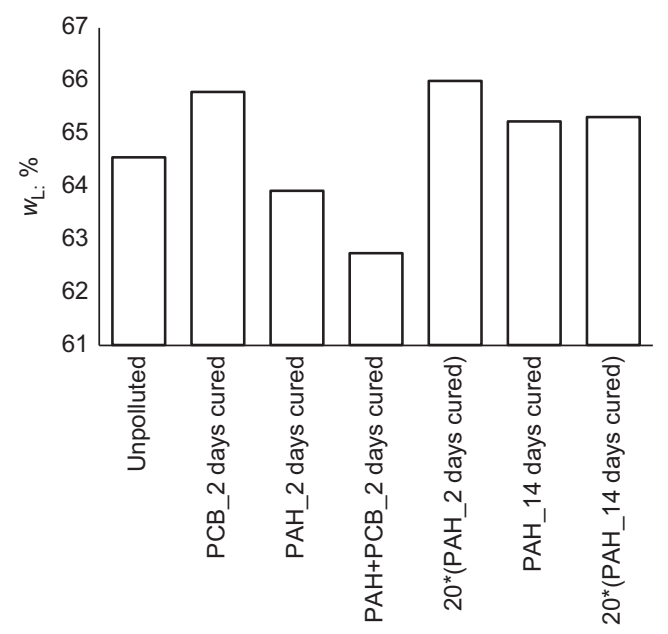

Fig. 8. Liquid limit determinations on a Mar Piccolo (MP) sediment sample at different concentrations of polychlorinated biphenyl (PCB) and polycyclic aromatic hydrocarbons (PAH), and after different curing times ( 2 days and 14 days)

\section{DISCUSSION}

Figure 6(a) highlights the limited variability of the mineralogical composition of the sediments in the basin, down to the ASP. Indeed, the profiles in the figure seem to confirm that the recent sediments were generated by the erosion and re-deposition of the ASP, as widely discussed in Lisco et al. (2015) and Cotecchia et al. (2021). The data have also provided evidence that the pore fluid composition is rather constant with depth and that the heavy metal ions are neither present in the pore fluid (Fig. 7(a)) nor available as exchangeable cations. It follows that, in the MP sediments, metals are likely to be absorbed by the skeleton and have a low tendency to migrate during the washing procedure (e.g. also in the case of the most contaminated S6-S sample). Such findings have been also confirmed by preliminary sequential extraction tests carried out by ARPA (2014), characterising the way in which the metals at the MP site interact with the soil matrix.

The geotechnical data in Table 1, along with the data plotted in Figs 3-5, outline a variability of the index and hydro-mechanical properties of the MP samples that form the subject of this study, which is representative of the overall variability at the site. The geotechnical properties of the samples S9-S and S12-S are at the extremes of such variability, despite the facts that their difference in mineralogy is limited to less than $10 \%$ of Sm content and their pore fluid composition is the same.

It follows that the reason for the recorded variability of the index properties should be sought in factors affecting the in situ soil conditions other than their skeleton composition, such as the OM content and the fossil content, since the pollutants have also been shown not to affect the index properties (see previous subsection entitled 'Chemical properties of the MP samples and effects of spiking tests').

In Fig. 3, for each of the data plotted in the activity chart, the values of Sm content, CEC, TOC and total inorganic carbon (TIC) have been reported, as well as the type of pollutants, when exceeding the thresholds set by law (ICRAM, 2004; Italian Republic, 2006). The figure reveals that the activity index of the samples at the lower and upper bounds in the chart is not consistent with their Sm content. In particular, S12-S, of highest activity, includes a low Sm content, whereas S9-S, of lowest activity, includes a high $\mathrm{Sm}$ content, confirming that it is not the mineralogy alone that is the factor controlling the geotechnical properties of the sediments. Indeed, when PI is plotted against either the Sm (Fig. 9(a)) or the OM content (TOC in Fig. 9(b)) - which are both factors the increase of which causes PI increase - the PI values of most samples increase with $\mathrm{Sm}$ and TOC, consistently with the trend found in the literature (e.g. Paul \& Barras, 1999; Mitchell \& Soga, 2005), except for samples S12-S and S9-S, which are outliers for the general trends. Even the most polluted sample, S6-S, fits the general trend between index properties and both mineralogical and organic content, confirming the spiking test results, which provides evidence that the out-of-limit concentrations of organic pollutants do not affect the plasticity of the MP sediments (Fig. 8).

Given all the findings reported above, the reason for the out-of-trend properties of samples S12-S and S9-S has been investigated, exploring their OM nature and their microstructural features.

\section{INVESTIGATION OF THE NATURE OF THE ORGANIC MATTER AND SEDIMENT MICROFABRICS \\ Nature of organic matter}

Thermogravimetry tests were performed to explore further the nature of the sediment skeleton and its OM content, 


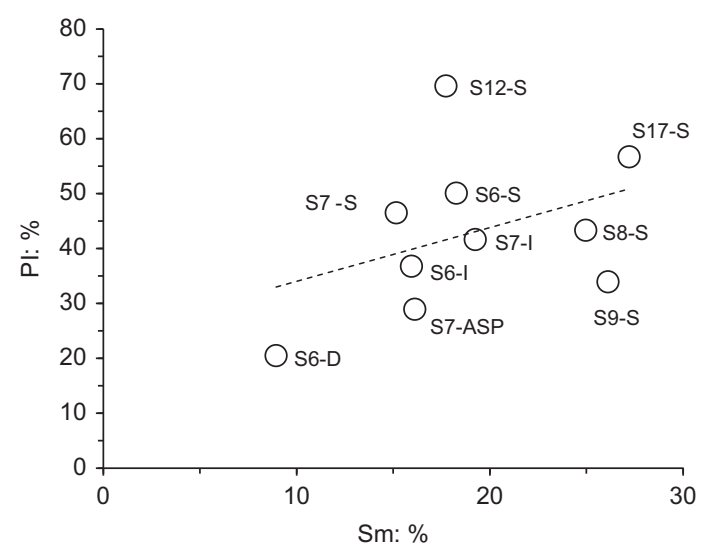

(a)

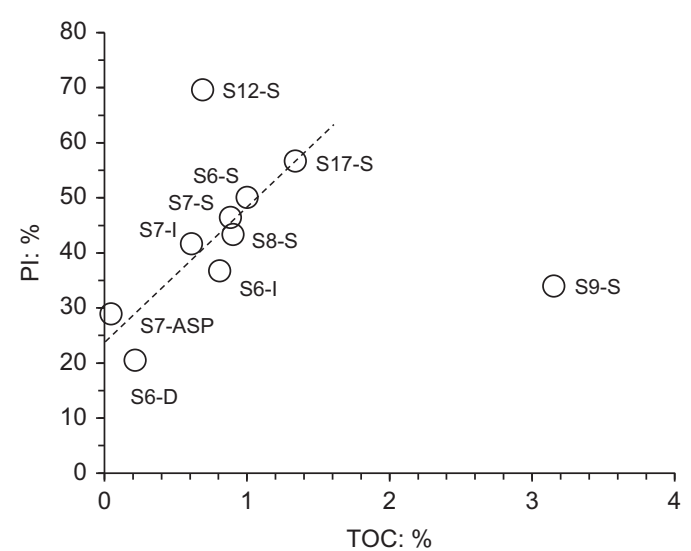

(b)

Fig. 9. Correlations between plasticity index (PI) and: (a) smectite content (Sm); (b) total organic carbon (TOC) content

based on the main thermal reactions occurring within different temperature ranges (Table 3 ; section $\mathrm{S} 2 \cdot 2$ in the online supplementary material). The resulting curves of $(a)$ the derivative mass loss (DTG), $(b)$ the carbon dioxide $\left(\mathrm{CO}_{2}\right)$ release and $(c)$ the sulfur dioxide $\left(\mathrm{SO}_{2}\right)$ release are shown in Figs 10, 11(a) and 11(b), respectively, for six shallow samples and for the ASP sample.

As reported in Table 3, for low temperature values $\left(T<200^{\circ} \mathrm{C}\right)$, the soil experiences the loss of adsorbed water and the dehydration of both the clay aggregates and swellable clay minerals (i.e. smectite). Consistently, the DTG curves of all the samples show a peak in the rate of mass loss at about $80-100^{\circ} \mathrm{C}$ (Fig. 10) and S17-S, that is the sample of highest $\mathrm{CF}$ and smectite content (Fig. 3), exhibits the maximum mass loss rate.

In the temperature range $220-620^{\circ} \mathrm{C}$, although the soil loses mass due to the dehydroxylation of the clay minerals (e.g. for kaolinite at $560^{\circ} \mathrm{C}$, for smectite at $500-700^{\circ} \mathrm{C}$; Table 3), a large part of the mass loss may also be due to OM degradation (Table 3). The weight loss in the lower part of this temperature range $\left(200-450^{\circ} \mathrm{C}\right)$ is associated with the combustion of carbohydrates and poorly altered OM, while that in the range $375-500^{\circ} \mathrm{C}$ is consequent to the degradation of more complex organic substances, such as humus, lignin and aromatic compounds. Given this explanation, the earliest DTG peak $\left(270^{\circ} \mathrm{C}\right)$ that is recorded for the sample of highest TOC, S9-S, suggests that in this sample the oxidation of a significant amount of recent biodegradable OM is occurring. The second DTG peak recorded in the sample at about $530^{\circ} \mathrm{C}$ also reveals the presence of humic components. Neither of these peaks is recorded for the other samples, all of which have lower TOC than that of S9-S (Table 2). Therefore, it may be expected that these two types of OM are present in sample S9-S and are the factors influencing its geotechnical properties, as further discussed later.

The lowest rate in mass loss upon heating in the temperature range $220-620^{\circ} \mathrm{C}$ is exhibited by the S7-ASP sample, which is of similar mineralogical composition to all the other samples but has the lowest organic matter. All the curves in Fig. 10 appear to confirm that the peaks in this temperature range are most likely the effect of OM degradation rather than the dehydroxylation of clay minerals.

For heating temperatures higher than $620^{\circ} \mathrm{C}$, the mass loss of the soil is related to the process of carbonate thermal decomposition (Table 3). At these temperatures, the DTG curves of S6-S, S7-S, S12-S and S7-ASP samples are characterised by an intense peak (Fig. 10). This is consistent with their similar TIC values, which are all higher than $3 \cdot 3 \%$. Instead, no peaks in DTG curves are observed for samples with TIC lower than $3 \cdot 3 \%$ - that is, S9-S, S17-S, S8-S.

It follows that the carbon dioxide release curves (Fig. 11(a)) confirm the interpretation discussed above, based upon the DTG curves. Carbon dioxide peaks are visible in the region of carbonate thermal degradation for samples with TIC larger than $3.3 \%$ and in that of OM degradation for sample S9-S, whereas they tend to disappear for the other samples. The shallow sample S9-S is also the only one exhibiting two evident peaks in the sulfur dioxide release curve (Fig. 11(b)), consistently with its highest

Table 3. Relevant thermal reactions upon heating at different temperature ranges (Dell'Abate et al., 2000; Melis \& Castaldi, 2004; Lopez-Capel et al., 2005; Maharaj et al., 2007; Emmerich, 2011; Kristl et al., 2016)

\begin{tabular}{|c|c|c|c|c|}
\hline $\begin{array}{l}\text { Up to } 300^{\circ} \mathrm{C} \\
\text { Loss of adsorbed water, } \\
\text { dehydration of the } \\
\text { interlayer cations of } \\
\text { swellable clay minerals }\end{array}$ & $\begin{array}{l}300-850^{\circ} \mathrm{C} \\
\text { Dehydroxylation of clay minera } \\
200-650^{\circ} \mathrm{C} \\
\text { Decomposition of organic matt } \\
200-450^{\circ} \mathrm{C} \\
\text { Biodegradable products } \\
210-320^{\circ} \mathrm{C} \\
\text { Combustion of carbohydrates } \\
270-375^{\circ} \mathrm{C} \\
\text { 'Fresh' organic matter: } \\
\text { - grass litter } \\
\text { - cellulose } \\
\text { - apple leaves (combustion of } \\
\text { carbohydrates) }\end{array}$ & $\begin{array}{l}\text { Is } \\
450-650^{\circ} \mathrm{C} \\
\text { Humic components } \\
400-520^{\circ} \mathrm{C} \\
\text { Thermal degradation o } \\
\text { structure } \\
375-430^{\circ} \mathrm{C} \\
\text { Lignin decomposition }\end{array}$ & $\begin{array}{l}\text { aromatic } \\
415-520^{\circ} \mathrm{C} \\
\text { Coal fraction }\end{array}$ & $\begin{aligned}> & 600^{\circ} \mathrm{C} \\
& \text { Carbonate thermal } \\
& \text { dissociation } \\
& \mathrm{XCO}_{3} \rightarrow \mathrm{XO}+\mathrm{CO}_{2}\end{aligned}$ \\
\hline
\end{tabular}




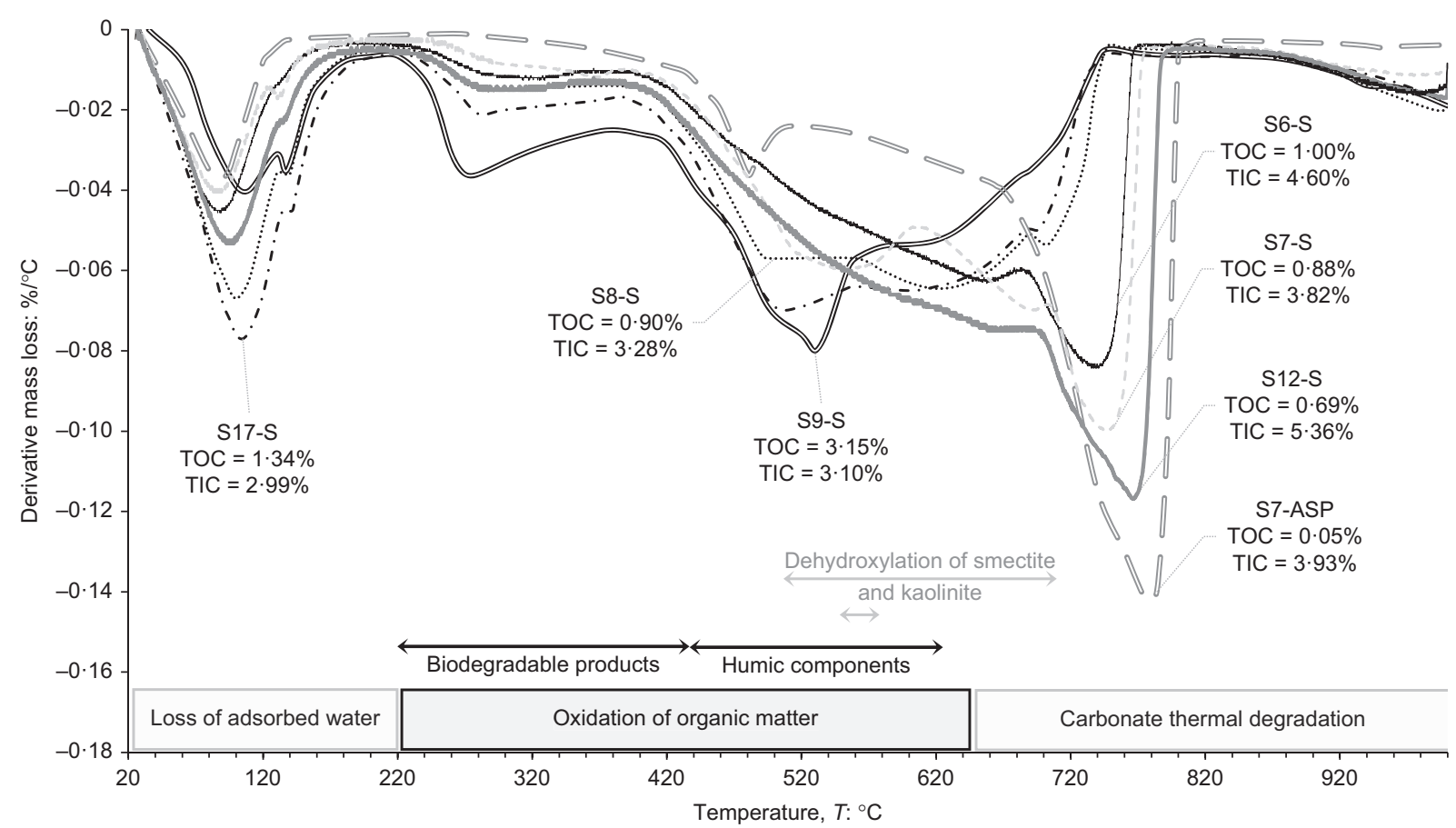

Fig. 10. Thermogravimetric derivative mass loss (DTG) curves of the Mar Piccolo (MP) shallow samples and the sub-Apennine clay (ASP) sample (TOC, total organic carbon; TIC, total inorganic carbon)

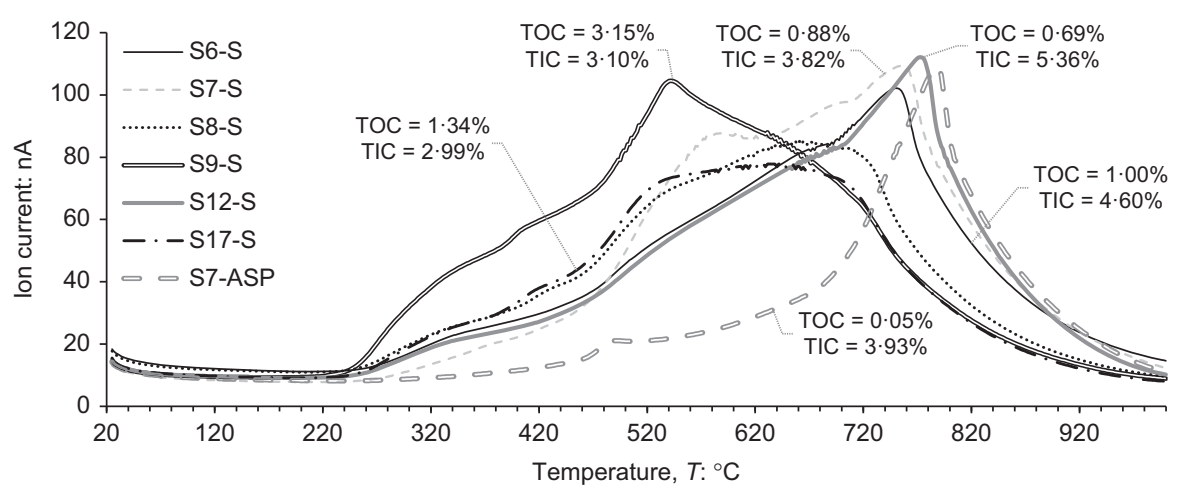

(a)

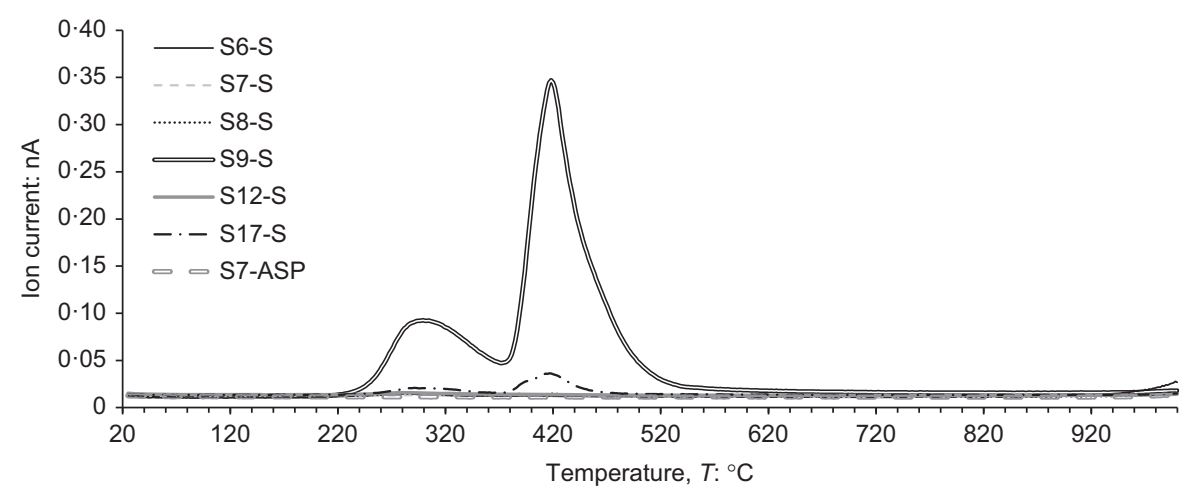

(b)

Fig. 11. (a) Carbon dioxide release and (b) sulfur dioxide release curves for six shallow samples and for the sub-Apennine clay (ASP) sample derived from thermogravimetry tests (TOC, total organic carbon; TIC, total inorganic carbon)

content of pyrite, suggesting that some OM mineralisation may have occurred under anoxic conditions.

\section{Pore size distributions}

The pore size distribution (PSD) of the MP samples of reference here is shown in Fig. 12. The MIP test (Diamond,
1970; Delage \& Lefebvre, 1984; section S2.3 in the online supplementary material) results show that the sediments collected by $1.5 \mathrm{~m}$ depth have a relatively large dominant pore size (DPS), between 2 and $6 \mu \mathrm{m}$, higher than that recorded for other soft clays, such as the Gulf of Guinea clay (Hattab et al., 2013, Fig. 12), sampled at $9.65 \mathrm{~m}$ bsf, and the St Marcel clay, sampled at 5.2 m depth (Delage \& Lefebvre, 


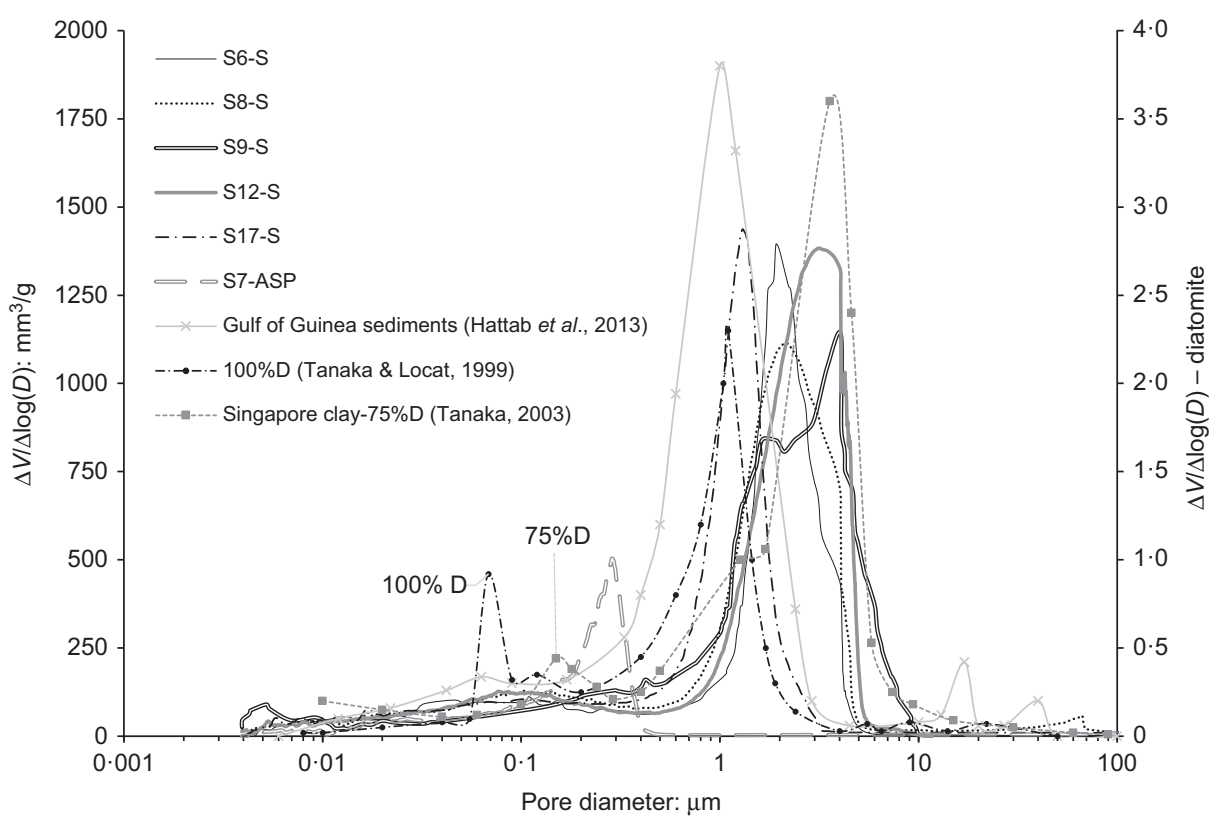

Fig. 12. Pore size distributions of Mar Piccolo (MP) samples compared with the curves of a soft clay (Hattab et al., 2013) and diatomaceous soils (Tanaka \& Locat, 1999; Tanaka, 2003) (D, diatomite)

1984). As expected, the deep ASP sample has a DPS of $0 \cdot 29 \mu \mathrm{m}-$ that is, close to that of the undisturbed ASP clays sampled in land (Guglielmi et al., 2018).

Figure 13 shows the DPS-CF plot for the tested samples. The data are close to a regression line, formalising how the DPS reduces (from $3 \cdot 14$ to $1.29 \mu \mathrm{m}$ ) as CF increases (from $30 \cdot 2$ to $65 \cdot 4 \%$ ), as already reported in the literature (e.g. Delage, 2010). Only samples S7-ASP and S9-S do not fit this trend. The large distance of the S7-ASP data from the regression line is consistent with the much lower compressibility of this sample, which is much stiffer than all the others because it is highly overconsolidated. Conversely, the offset of the DPS-CF data of the normally consolidated sample S9-S needs to be further explained, as reported later.

Irrespective of their different $\mathrm{CF}$, the shallow samples S12-S, S17-S, S8-S and S6-S all exhibit a mild bimodal PSD, with a secondary DPS at about $0.11 \mu \mathrm{m}$. The highest frequency of the secondary DPS $(0 \cdot 11 \mu \mathrm{m})$ is recorded for sample S12-S, of relatively small CF, whereas no clear secondary DPS is recorded for the most organic sample, S9-S, also richest in CF. Bimodal PSD, like that recorded for most of the shallow MP samples, has been found either in

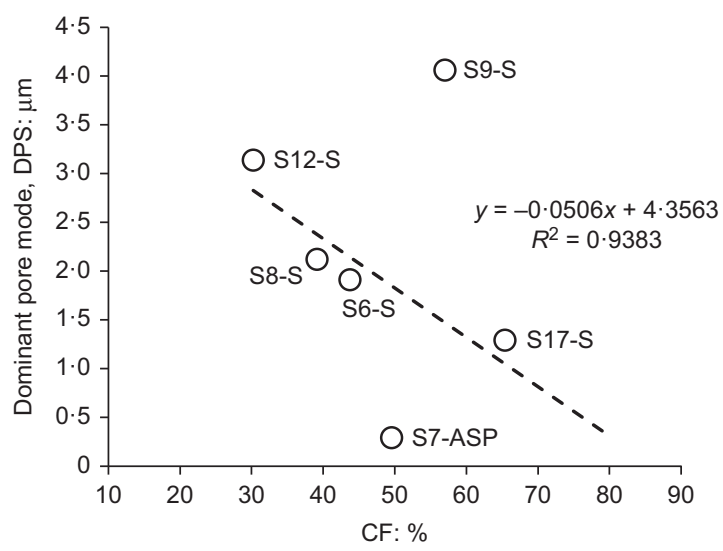

Fig. 13. Correlation between clay fraction (CF) and dominant pore mode (DPS) high-plasticity clays (Hattab et al., 2013; Pineda et al., 2016; Guglielmi et al., 2018) or in fossiliferous clays, or in soils rich in diatoms (Fig. 12). MIP tests carried out on kaolin (Tanaka \& Locat, 1999) and Singapore clay mixed with diatoms (Tanaka, 2003) showed that diatoms may determine a secondary DPS at $0 \cdot 07-0 \cdot 15 \mu \mathrm{m}$. The scanning electron microscopy (SEM) analyses in the following will show that diatoms are the main source of the bimodal PSD of S12-S.

\section{SEM and energy-dispersive $X$-ray analyses}

The SEM analyses (section $\mathrm{S} 2 \cdot 3$ in the online supplementary material) carried out on the MP samples provide evidence regarding their content of microfossils and diatoms (Figs 14 and 15). In general, foraminifera shells can be recognised in all the samples, either shallow (e.g. S17-S in Fig. 14(a)) or deep, since foraminifera shells occur also in the parent marine clay, ASP, when sampled inland (Cotecchia \& Chandler, 1998). Furthermore, SEM images of fractures through samples - for example, S9-S - show the presence of framboid pyrite (Fig. 14(b)) and fragments of diatoms surrounded by pyrite (Fig. 14(c)).

Among all the samples, S12-S has been found to be the richest in porous fossils (Figs 15 (a) to $15(\mathrm{~h})$ ), either siliceous or calcareous (according to the energy-dispersive X-ray analyses). As an example, Fig. 15(a) shows a fossil composed of calcium (Ca in Fig. 15(b)), surrounded by framboid pyrite (sulfur, S, in Fig. 15(c)) and by aggregated clay particles. Furthermore, many porous structures of less than $300 \mu \mathrm{m}$ in size, whose pores have diameter of less than $20 \mu \mathrm{m}$ (Figs 15(d) and 15(e)), have been detected, as well as several porous diatoms (Figs $15(\mathrm{f})$ and $15(\mathrm{~g})$ ), found to be formed of silicon (Si) and oxygen (O) (Fig. 15(h)), as expected, since diatoms are single-cell algae composed of $90 \%$ silica. Accordingly, the results of atomic absorption spectrometry on biogenic silica (Mortlock \& Froelich (1989) and section $\mathrm{S} 2 \cdot 4$ in the online supplementary material) have confirmed that the S12-S sample embodies the highest amount of biogenic silicon $(15.9 \mathrm{mg} / \mathrm{g})$ among the samples included here $(13 \cdot 5-10 \cdot 3 \mathrm{mg} / \mathrm{g})$. 


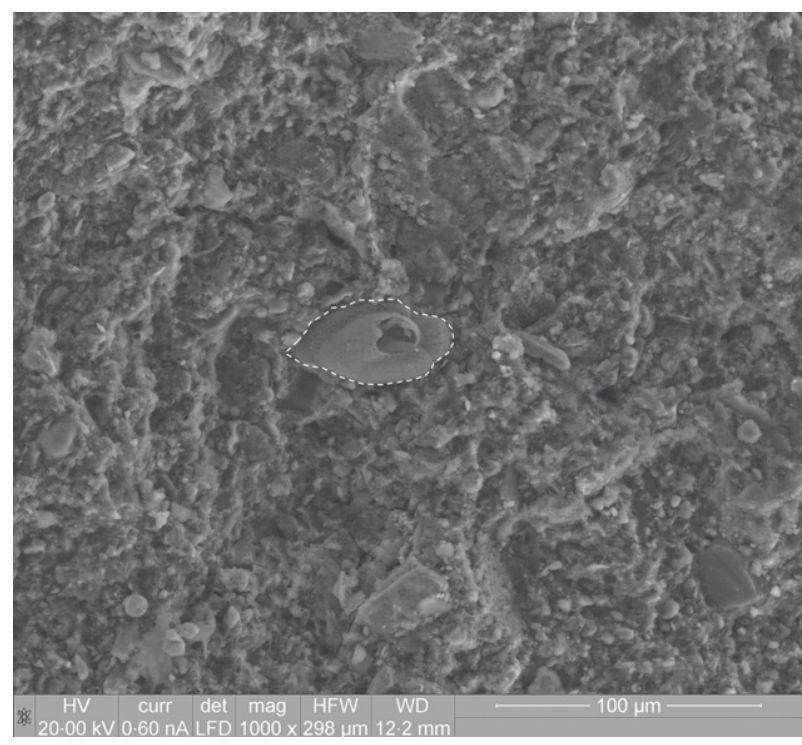

(a)

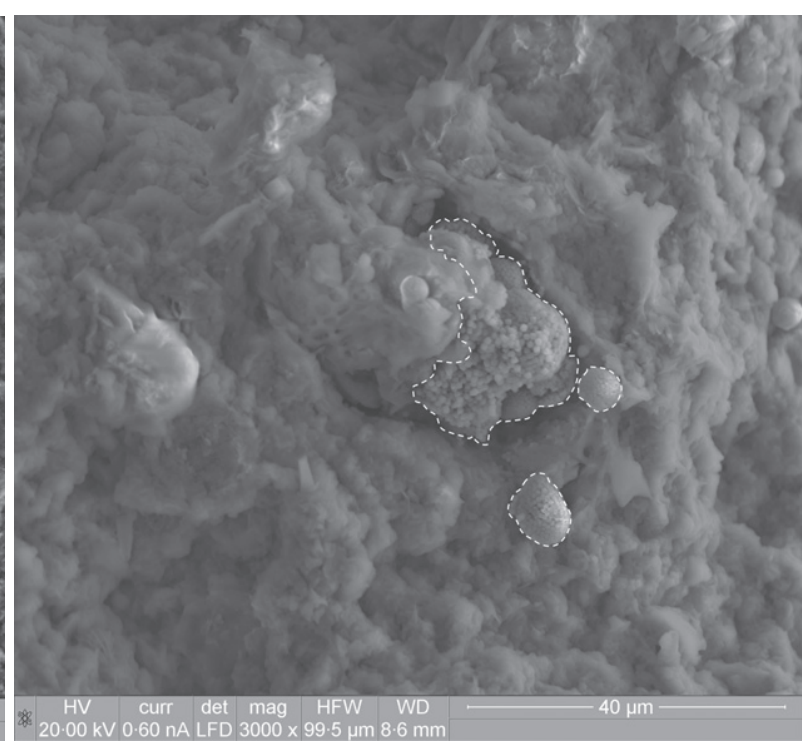

(b)

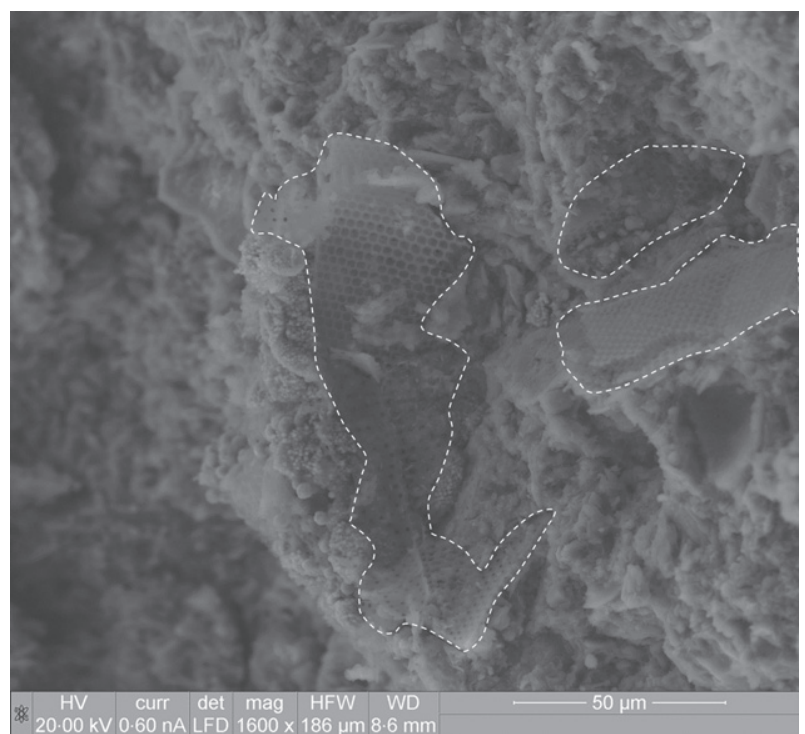

(c)

Fig. 14. Scanning electron micrographs showing: (a) a foraminifera shell in S17-S sample; (b) assemblages of framboid pyrite of different dimensions in S9-S sample; and (c) surrounding portions of diatoms

\section{DISCUSSION OF THE INTEGRATED DATABASE}

The variability in the thermal response of the MP samples during the TG tests has been shown to reflect their variability in both mineralogy and organic content.

With regard to sample S9-S, which is one of the outliers with respect to the general trend in Fig. 3, its out-of-trend properties could be attributable to both the high content and the nature of its OM. The significant content of pyrite, as confirmed by the XRD data (Table 2), the sulfur dioxide release curve (Fig. 11(b)) and the SEM images (Figs 14(b) and 14(c)), indicates that the OM degradation is a major process taking place in this sample. In particular, this is a process occurring under anoxic conditions, through which the $\mathrm{OM}$ is mineralised and enters an anaerobic biological chain, which includes the sulfate and iron reductions and the formation of pyrite, by reaction of iron oxides-hydroxides and hydrogen sulfide (Schulz \& Zabel, 2000). Furthermore, it has been recognised that at least part of the OM in S9-S is recent and still subject to degradation processes, since this sample exhibited a response to heating typical of soils that include both biodegradable and humus products.
Since sulfate reducers can use relatively small organic molecules, they are generally associated with the presence of microbial populations that degrade complex organic compounds. It follows that the formation of pyrite is indicative not only of the anaerobic OM degradation in S9-S, but also of the abundance of the microbial population, which feeds off the organics within the sediments and oxidises the OM (Konhauser \& Urrutia, 1999; DeJong et al., 2013; Colreavy et al., 2019).

Both organic substances and microbial populations have a binding effect on the soil particles (e.g. Bhaskar \& Bhosle, 2005; Bobet at al., 2011). Varghese et al. (2019) recognised that the addition of OM increases the number of pores due to the flocculation of clay particles determined by the $\mathrm{OM}$ and that such an aggregation effect is highest for clays mixed with non-humic and rapidly decomposing organic substances. Therefore, it is supposed that the OM present in S9-S sample aggregates the clay particles and reduces its plasticity and activity indexes, which would be otherwise much higher given the high $\mathrm{CF}$ and $\mathrm{Sm}$ contents of the sample (Fig. 3). It is worth highlighting that the high $\mathrm{CF}$ of this sample $(57 \%$, 


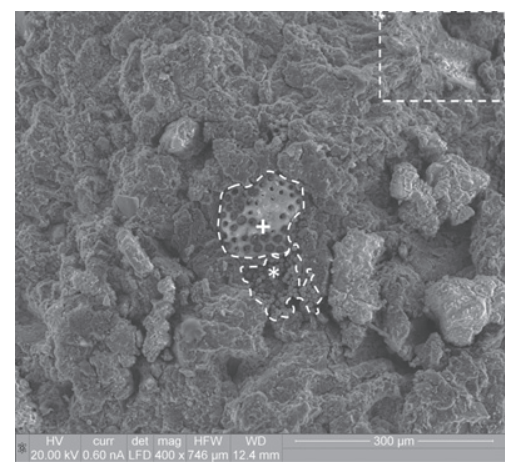

(a)

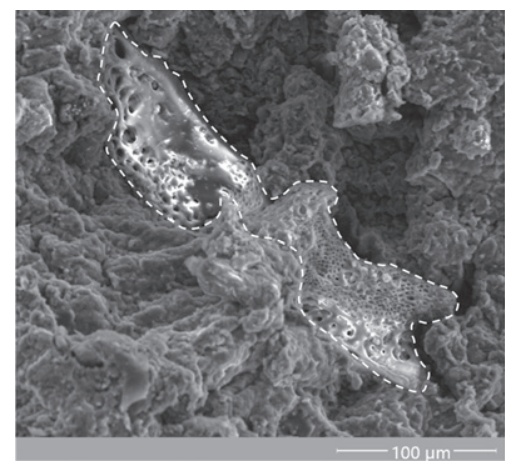

(d)

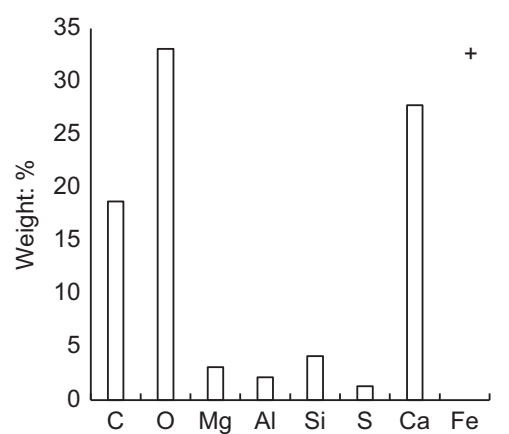

(b)

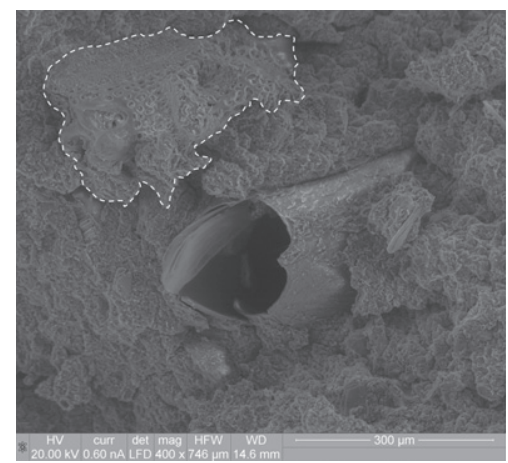

(e)

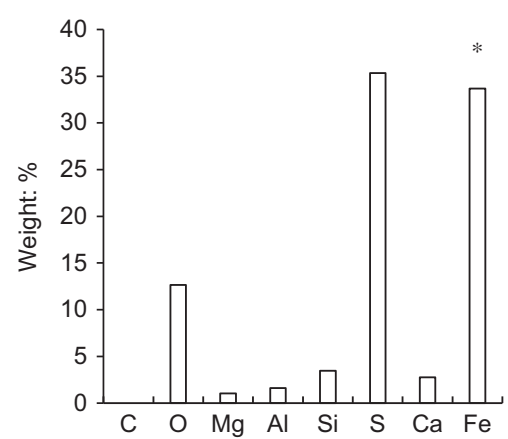

(c)

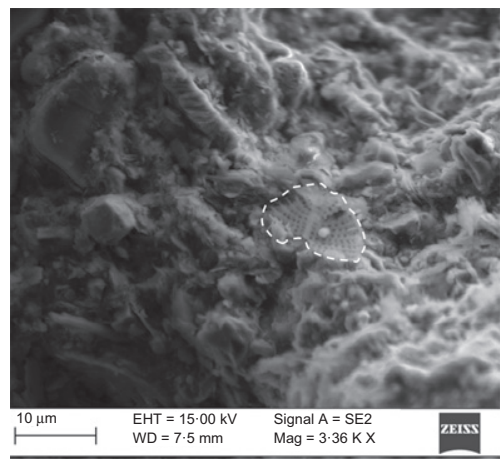

(f)

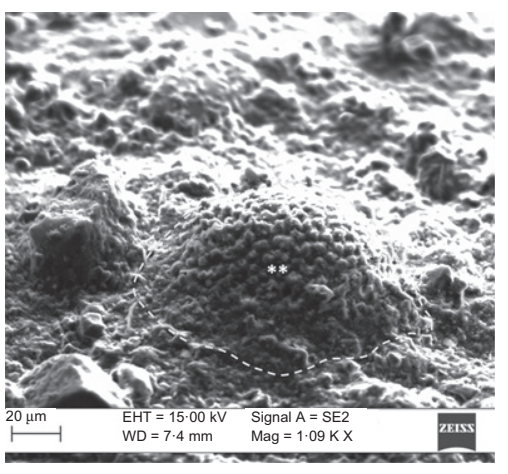

(g)

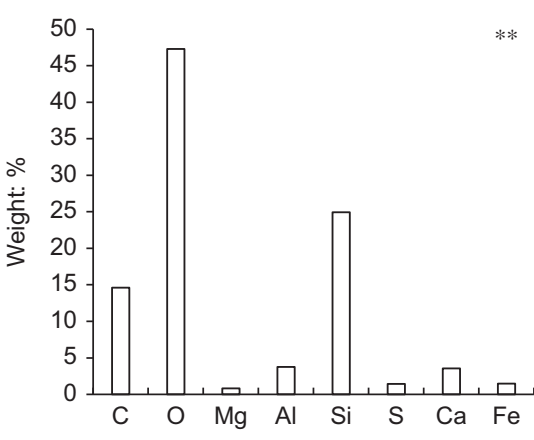

(h)

Fig. 15. Scanning electron micrographs and elemental analysers of various layers of sample S12-S. (a) Porous fossils mainly composed by (b) calcium, also surrounded by (c) framboid pyrite; (d), (e) porous structures less than $300 \mu \mathrm{m}$ in size; (f), (g) diatoms of different size; (h) corresponding prevalence of silicon

Table 1) has been assessed through the standard granulometry testing (ASTM D422 (ASTM, 2007)), through which the aggregates determined by the OM are disaggregated by adding the dispersion agent. Given this explanation, the $A$ index value measured for S9-S (Fig. 3) is the ratio of the low $\mathrm{PI}$, the effect of the particle aggregation caused by the type of $\mathrm{OM}$ present in this sample, and its total $\mathrm{CF}$, measured after the disaggregation of the aggregates. It is likely that the very high DPS measured for this sample (Fig. 13) is representative of the inter-aggregate porosity confined by the particle aggregates, in turn generated by the OM (Fig. 13). The absence of an intra-aggregate porosity in this sample (Fig. 12) is likely to be the effect of the sealing of the intra-aggregate pores, determined by the colonies of micro-organisms.

With regard to the other outlier sample S12-S (Fig. 3), the data discussed before justify its out-of-trend activity and double porosity. In particular, the PSD of this sample is characterised by a secondary DPS whose frequency is the highest with respect to the secondary DPS of the other samples, and a principal DPS corresponding to a high pore size. This is typically the case for clays including a large diatom content (Tanaka \& Locat, 1999; Tanaka, 2003; Lee et al., 2011; Fig. 12). The higher amount of microfossils and diatoms documented for this sample through the micro-scale analyses is recognised to be the source of its peculiar PSD and its out-of-trend values of PI, $A$ and $C_{\mathrm{C}}$, which are not consistent with its low $\mathrm{CF}$ and $\mathrm{Sm}$ content (Fig. 3). The effect of the microfossil and diatom contents on the geotechnical properties recorded for S12-S have been observed also for the Gulf of Guinea marine sediments (Tanaka \& Locat, 1999) and the Bogotá lacustrine clay (Caicedo et al., 2018). The breakage of the microfossils during compression is likely to be the source of the very high compressibility of the sample S12-S, since a similar behaviour has been recorded for other clays rich in microfossils (Tanaka \& Locat, 1999). The literature reports that the abundance of diatoms also determines an increase in void ratio, permeability coefficient and permeability index (Tanaka, 2003; Lee et al., 2011), and this seems to be the case also for sample S12-S, which shows the highest $k_{e_{0}}$ value among all the tested samples (Fig. 5). 


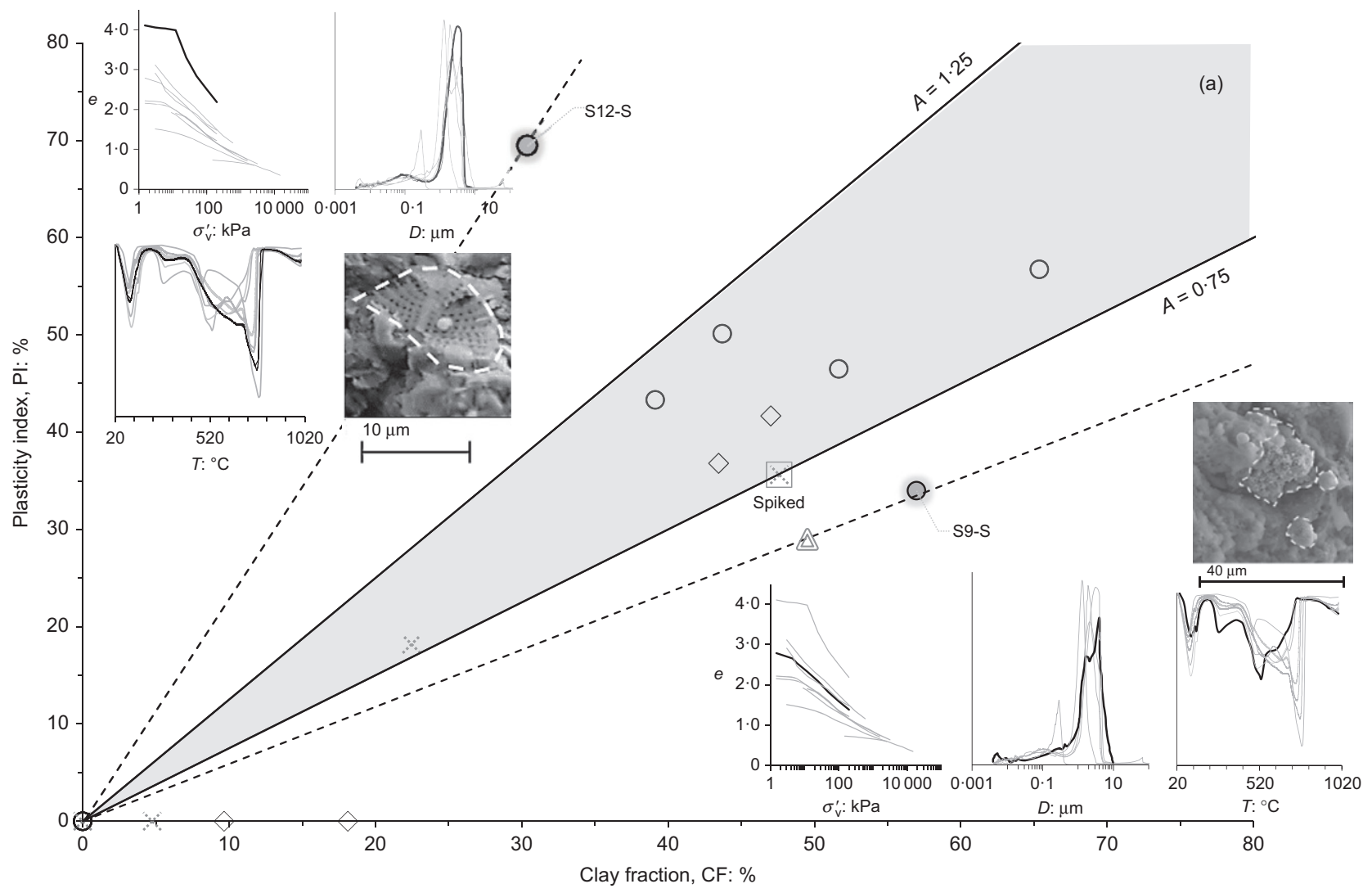

Fig. 16. Framework of the multi-scale interactions underlying the Mar Piccolo (MP) sediments

\section{CONCLUSIONS}

The main results of the present research contribute to illustrate the extent to which the geotechnical properties of marine sediments may not depend only on the soil granulometry and mineralogy, especially when they have been recently deposited in the ecosystem location of a biocenosis rich in organic compounds.

In the case of the MP system, the tests on the sampled sediments have shown that the anthropogenic pollutants, either heavy metals or organic compounds, the abundance of which has been widely documented at the site (e.g. Cardellicchio et al., 2007; Cotecchia et al., 2021), do not impact significantly on the sediment's geotechnical properties. This finding has been demonstrated by the comparative analysis of the geotechnical properties of the polluted sample S6-S with those of the other tested unpolluted samples, and by the results of the spiking tests carried out in the laboratory.

Irrespective of their degree of pollution, all the tested samples (within the grey cone in Fig. 16), with the exception of two, showed both PI and $A$ values increasing with the OM content, according to a linear regression law consistent with the trends usually recognised in the literature (e.g. Paul \& Barras, 1999; Mitchell \& Soga, 2005). Most of the data confirm that, in addition to the soil mineralogy and granulometry, the OM content is the other natural factor affecting the geotechnical properties of sediments.

The dependency of the geotechnical properties on granulometry, mineralogy and OM content of the soil, however, is not sufficient to predict the properties of the two samples S9-S and S12-S, which, for example, do not fit the PI-OM law derived for the others. The research has demonstrated that when the OM is abundant and composed by degradable compounds, as in a biologically rich ecosystem such as the MP basin, the OM may even cause a major drop in PI and $A$ values, because of its capacity to aggregate the clay particles. Such a phenomenon has impacted the PI and $A$ values of S9-S, as well as its PSD and permeability (Fig. 16, bottom right inset).

Furthermore, the study has shown that microfossils and diatoms can trap and store water and have an impact on the soil water content, as in the case of sample S12-S (Fig. 16, top left inset); this makes the liquid limit very high, although the sample does not behave as a high-plasticity clay, since it does not include the large clay fraction of high-plasticity soil. The abundance of the microfossils and diatoms also influences the sediment PSD and compressibility.

Overall, the results of the study represent a step forward in the interpretation of the behaviour of shallow sediments in marine basins and, as such, may have innovative implications regarding the selection of remediation technologies in the case of polluted sediments that need to be subjected to reclamation.

\section{ACKNOWLEDGEMENTS}

The site investigation of MP basin has been possible thanks to an ample multidisciplinary project funded by the Special Commissioner for urgent measures of reclamation, environmental improvements and redevelopment of Taranto (south Italy), Dr Vera Corbelli, as appointed by the Italian government. The activities have also benefitted from the support of the staff at both the IGT Claylab of ETH Zurich (A. Röthlisberger and M. Rothaupt) and the Geotechnical laboratory at Politecnico di Bari (E. Miccoli).

\section{NOTATION}

$A$ activity index

$C_{\mathrm{c}}$ compression index 
$C_{\mathrm{c} \_\mathrm{AV}}$ average compression index

$C_{k} \quad$ permeability index $(=\Delta e / \Delta \log k)$

void ratio

$e_{0} \quad$ initial void ratio

$k$ coefficient of permeability

$k_{e_{0}}$ coefficient of permeability at initial void ratio, $e_{0}$

$T$ temperature

$w$ water content

$w_{\mathrm{L}}$ liquid limit

$w_{\mathrm{P}} \quad$ plastic limit

$\gamma$ bulk unit weight

$\sigma_{\mathrm{v} 0}^{\prime} \quad$ in situ vertical effective stress

$\sigma_{\mathrm{vc}}^{\prime} \quad$ vertical preconsolidation stress

$\sigma_{\mathrm{vy}}^{\prime} \quad$ yield vertical effective stress

\section{REFERENCES}

Adamo, F., Andria, G., Bottiglieri, O., Cotecchia, F., Di Nisio, A., Miccoli, D., Sollecito, F., Spadavecchia, M., Todaro, F., Trotta, A. \& Vitone, C. (2018). Geolab, a measurement system for the geotechnical characterization of polluted submarine sediments. Measurement 127, 335-347, https://doi.org/10.1016/ j.measurement.2018.06.001.

ARPA Puglia (Agenzia Regionale per la Protezione Ambiantale Puglia) (2014). Mar Piccolo of Taranto - scientific-technical report on the interaction between the environmental system and contaminants flows from primary and secondary sources. Technical report. Bari, Italy: ARPA Puglia (in Italian).

ASTM (2000). D4542: Standard test methods for pore water extraction and determination of the soluble salt content of soils by refractometer. West Conshohocken, PA, USA: ASTM International.

ASTM (2007). D422: Standard test method for particle-size analysis of soils. West Conshohocken, PA, USA: ASTM International.

ASTM (2011). D2435: Standard test methods for one-dimensional consolidation properties of soils using incremental loading. West Conshohocken, PA, USA: ASTM International.

ASTM (2017). D4318: Standard test methods for liquid limit, plastic limit, and plasticity index of soils. West Conshohocken, PA, USA: ASTM International.

Bennett, R. H., Lehman, L., Hulbert, M. H., Harvey, G. R., Bush, S. A., Forde, E. B., Crews, P. \& Sawyer, W. B. (1985). Interrelationships of organic carbon and submarine sediment geotechnical properties. Mar. Geotechnol. 6, No. 1, 62-98.

Bhaskar, P. V. \& Bhosle, N. B. (2005). Microbial extracellular polymeric substances in marine biogeochemical processes. Curr. Sci. 88, No. 1, 45-53.

Bish, D. \& Plötze, M. (2011). X-ray powder diffraction with emphasis on qualitative and quantitative analysis in industrial mineralogy. In Advances in the characterization of industrial minerals (ed. G. E. Christidis), EMU notes in mineralogy vol. 9, pp. 35-76. Twickenham, UK: European Mineralogical Union and the Mineralogical Society of Great Britain \& Ireland.

Bobet, A., Hwang, J., Johnston, C. T. \& Santagata, M. (2011). One-dimensional consolidation behavior of cement-treated organic soil. Can. Geotech. J. 48, No. 7, 1100-1115.

Booth, J. S. \& Dahl, A. G. (1986). A note on the relationships between organic matter and some geotechnical properties of a marine sediment. Mar. Geotechnol. 6, No. 3, 281-297.

BSI (1990). BS 1377: Methods of test for Soils for civil engineering purposes - Part 2: Classification tests. London, UK: BSI.

Burland, J. B. (1990). On the compressibility and shear strength of natural clays. Géotechnique 40, No. 3, 329-378, https://doi.org/ 10.1680/geot.1990.40.3.329.

Caicedo, B., Mendoza, C., López, F. \& Lizcano, A. (2018). Behavior of diatomaceous soil in lacustrine deposits of Bogotá, Colombia. J. Rock Mech. Geotech. Engng 10, No. 2, 367-379.

Calvello, M., Lasco, M., Vassallo, R. \& Di Maio, C. (2005). Compressibility and residual shear strength of smectitic clays: influence of pore aqueous solutions and organic solvents. Riv. Ital. di Geotec. 2005, No. 1, 34-46.

Cardellicchio, N., Buccolieri, A., Giandomenico, S., Lopez, L., Pizzulli, F. \& Spada, L. (2007). Organic pollutants (PAHs PCBs) in sediments from the Mar Piccolo in Taranto (Ionian Sea. Southern Italy). Mar. Pollut. Bull. 55, No. 10-12, 451-458.
CEN (2004). EN 14039:2004. Characterization of waste determination of hydrocarbon content in the range of $\mathrm{C} 10$ to C40 by gas chromatography. Brussels, Belgium: European Committee for Standardization (CEN).

CEN (2016). EN 15308:2016. Characterization of waste determination of selected polychlorinated biphenyls (PCB) in solid waste by gas chromatography with electron capture or mass spectrometric detection. Brussels, Belgium: European Committee for Standardization.

Chapman, D. L. (1913). A contribution to the theory of electrocapillarity. Philos. Mag. 25, No. 148, 475-481.

Colreavy, C., O’loughlin, C. D., Bishop, D. \& Randolph, M. F. (2019). Effect of soil biology and pore water chemistry on a lakebed sediment. Géotechnique 69, No. 11, 959-970, https:// doi.org/10.1680/jgeot.16.P.308.

Cotecchia, F. \& Chandler, R. J. (1998). One-dimensional compression of a natural clay: structural changes and mechanical effects. In The geotechnics of hard soils-soft rocks: proceedings of the second international symposium on hard soils-soft rocks (eds A. Evangelista and L. Picarelli), pp. 103-114. Rotterdam, the Netherlands: A. A. Balkema.

Cotecchia, F., Vitone, C., Sollecito, F., Mali, M., Miccoli, D., Petti, R., Milella, D., Ruggieri, G., Bottiglieri, O., Santaloia, F., De Bellis, P., Cafaro, F., Notarnicola, M., Todaro, F., Adamo, F., Di Nisio, A., Lanzolla, A. M. L., Spadavecchia, M., Moretti, M., Agrosì, G., De Giosa, F., Fago, P., Lacalamita, M., Lisco, S., Manzari, P., Mesto, E., Romano, G., Scardino, G., Schingaro, E., Siniscalchi, A., Tempesta, G., Valenzano, E., Mastronuzzi, G., Cardellicchio, N., Di Leo, A., Spada, L., Giandomenico, S., Calò, M., Uricchio, V., Mascolo, G., Bagnuolo, G., Ciannarella, R., Tursi, A., Cipriano, G., Cotugno, P., Sion, L., Carlucci, R., Capasso, G., De Chiara, G., Pisciotta, G., Velardo, R. \& Corbelli, V. (2021). A geo-chemo-mechanical study of a highly polluted marine system (Taranto, Italy) for the enhancement of the conceptual site model. Sci. Rep. 11, article 4017, https://doi.org/10.1038/s41598-021-82879-w.

Degens, E. T. (1965). Geochemistry of sediments. Englewood Cliffs, NJ, USA: Prentice-Hall.

DeJong, J. T., Soga, K., Kavazanjian, E., Burns, S. Van Paassen, L. A., Al Qabany, A., Aydilek, A., Bang, S. S., Burbank, M., Caslake, L. F., Chen, C. Y., Cheng, X., Chu, J., Ciurli, S., Esnault-Filet, A., Fauriel, S., Hamdan, N., Hata, T., Inagaki, Y., Jefferis, S., Kuo, M., Laloui, L., Larrahondo, J., Manning, D. A. C., Martinez, B., Montoya, B. M., Nelson, D. C., Palomino, A., Renforth, P., Santamarina, J. C., Seagren, E. A., Tanyu, B., Tsesarsky, M. \& Weaver, T. (2013). Biogeochemical processes and geotechnical applications: progress, opportunities and challenges. Géotechnique 63, No. 4, 287-301, https://doi.org/10.1680/geot.SIP13.P.017.

Delage, P. (2010). A microstructure approach to the sensitivity and compressibility of some Eastern Canada sensitive clays. Géotechnique 60, No. 5, 353-368, https://doi.org/10.1680/geot. 2010.60.5.353.

Delage, P. \& Lefebvre, G. (1984). Study of the structure of the sensitive Champlain clay and of its evolution during consolidation. Can. Geotech. J. 21, No. 1, 21-35.

Dell'Abate, M. T., Benedetti, A. \& Sequi, P. (2000). Thermal methods of organic matter maturation monitoring during a composting process. J. Therm. Anal. Calorim. 61, No. 2, 389-396.

Di Maio, C. (1996). Exposure of bentonite to salt solution: osmotic and mechanical effects. Géotechnique 46, No. 4, 695-707, https://doi.org/10.1680/geot.1996.46.4.695.

Diamond, S. (1970). Pore size distributions in clays. Clays Clay Miner. 18, No. 1, 7-23.

Diaz-Rodriguez, J. A., Lozano-Santa Cruz, R., Davila-Alcocer, V. M., Vallejo, E. \& Giron, P. (1998). Physical, chemical, and mineralogical properties of Mexico city sediments: a geotechnical perspective. Can. Geotech. J. 35, No. 4, 600-610.

DIN (Deutsches Institut für Normung) (2012). EN 15936. Sludge, treated biowaste, soil and waste - determination of total organic carbon (TOC) by dry combustion. Berlin, Germany: Deutsches Institut für Normung.

Döbelin, N. \& Kleeberg, R. (2015). Profex: a graphical user interface for the Rietveld refinement program BGMN. J. Appl. Crystallogr. 48, No. 5, 1573-1580. 
Emmerich, K. (2011). Thermal analysis in the characterisation and processing of industrial minerals. In Advances in the characterization of industrial minerals (ed. G. E. Christidis), EMU notes in mineralogy vol. 9, pp. 129-170. Twickenham, UK: European Mineralogical Union and the Mineralogical Society of Great Britain \& Ireland.

EPA (US Environmental Protection Agency) (1996). METHOD 3052. Microwave assisted digestion of siliceous and organically based matrices. Washington, DC, USA: US Environmental Protection Agency.

EPA (1998). METHOD 8270D. Semivolatile organic compounds by gas chromatography/mass spectrometry (GCIMS). Washington, DC, USA: US Environmental Protection Agency.

Giandomenico, S., Cardellicchio, N., Spada, L., Annicchiarico, C. \& Di Leo, A. (2016). Metals and PCB levels in some edible marine organisms from the Ionian Sea: dietary intake evaluation and risk for consumers. Environ. Sci. Pollut. Res. 23, No. 13, 12596-12612, https://doi.org/10.1007/s11356-015-5280-2.

Goodarzi, A. R., Najafi Fateh, S. \& Shekary, H. (2016). Impact of organic pollutants on the macro and microstructure responses of Na-bentonite. Appl. Clay Sci. 121-122, No. C, 17-28.

Gouy, G. (1910). Electric charge on the surface of an electrolyte. J. Physics 4, No. 9, 457-468.

Guglielmi, S., Cotecchia, F., Cafaro, F. \& Gens, A. (2018). Microstructural changes underlying the macro-response of a stiff clay. In Micro to macro mathematical modelling in soil mechanics (eds P. Giovine, P. Mariano and G. Mortara), Trends in Mathematics, pp. 89-97. Cham, Switzerland: Birkhäuser.

Hattab, M., Hammad, T., Fleureau, J. M. \& Hicher, P. Y. (2013). Behaviour of a sensitive marine sediment: microstructural investigation. Géotechnique 63, No. 1, 71-84, https://doi.org/ 10.1680/geot.10.P.104.

Husein Malkawi, A. I., Alawneh, A. S. \& Abu-Safaqah, O. (1999). Effects of organic matter on the physical and the physicochemical properties of an illitic soil. Appl. Clay Sci. 14, No. 5-6, 257-278.

ICRAM (Istituto Centrale per la Ricerca Scientifica e tecnologica applicata al Mare) (2004). Doc \# CII-Pr-PU-TA-valori intervento-01.04. Rome, Italy: ICRAM (in Italian).

Imai, G., Tsoruya, K. \& Yano, K. (1978). A treatment of salinity in water content determination of very soft clays. Technical note. Soils Found. 19, No. 3, 84-89.

Italian Republic (2006). Decreto Legislativo 3 aprile 2006, n. 152 "Norme in materia ambientale". Gazzetta Ufficiale della Repubblica Italiana, Serie Generale 88, Suppl. Ordinario n. 96. Rome, Italy: Repubblica Italiana (in Italian).

Jang, J. \& Santamarina, J. C. (2016). Fines classification based on sensitivity to pore-fluid chemistry. J. Geotech. Geoenviron. Engng 142, No. 4, 06015018.

Kaya, A. \& Fang, H. Y. (2005). Experimental evidence of reduction in attractive and repulsive forces between clay particles permeated with organic liquids. Can. Geotech. J. 42, No. 2, 632-640.

Konhauser, K. O. \& Urrutia, M. M. (1999). Bacterial clay authigenesis: a common biogeochemical process. Chem. Geol. 161, No. 4, 399-413.

Kralj, M., De Vittor, C., Comici, C., Relitti, F., Auriemma, R., Alabiso, G. \& Del Negro, P. (2016). Recent evolution of the physical-chemical characteristics of a site of national interest the Mar Piccolo of Taranto (Ionian Sea) - and changes over the last 20 years. Environ. Sci. Pollut. Res. 23, No. 13, 12675-12690.

Kristl, M., Muršec, M., Šuštar, V. \& Kristl, J. (2016). Application of thermogravimetric analysis for the evaluation of organic and inorganic carbon contents in agricultural soils. J. Therm. Anal. Calorim. 123, No. 3, 2139-2147.

Lee, C., Yun, T. S., Lee, J. S., Bahk, J. J. \& Santamarina, J. C. (2011). Geotechnical characterization of marine sediments in the Ulleung Basin, East Sea. Engng Geol. 117, No. 1, 151-158.

Levesque, C. L., Locat, J. \& Leroueil, S. (2007). Characterisation of postglacial sediments of the Saguenay Fjord, Quebec, Canada. In Characterisation and engineering properties of natural soils (eds T. S. Tan, K. K. Phoon, D. W. Hight and S. Leroueil), pp. 2645-2677. London, UK: Taylor \& Francis Group.
Lisco, S., Corselli, C., De Giosa, F., Mastronuzzi, G., Moretti, M., Siniscalchi, A., Marchese, F., Bracchi, V., Tessarolo, C. \& Tursi, A. (2015). Geology of Mar Piccolo, Taranto (southern Italy): the physical basis for remediation of a polluted marine area. J. Maps 12, No. 1, 173-180.

Lopez-Capel, E., Sohi, S. P., Gaunt, J. L. \& Manning, D. A. C. (2005). Use of thermogravimetry-differential scanning calorimetry to characterize modelable soil organic matter fractions. Soil Sci. Soc. Am. J. 69, No. 1, 136-140.

Maharaj, S., Barton, C. D., Karathanasis, T. A. D., Rowe, H. D. \& Rimmer, S. M. (2007). Distinguishing 'new' from 'old' organic carbon on reclaimed coal mine sites using thermogravimetry: method development. Soil Sci. 172, No. 4, 292-301.

Meier, L. \& Kahr, G. (1999). Determination of the cation exchange capacity (CEC) of clay minerals using the complexes of copper (II) ion with triethylenetetramine and tetraethylenepentamine. Clays Clay Miner. 47, No. 3, 386-388.

Melis, P. \& Castaldi, P. (2004). Thermal analysis for the evaluation of the organic matter evolution during municipal solid waste aerobic composting process. Thermochim. Acta 413, No. 1-2, 209-214.

Mitchell, J. K. \& Santamarina, J. C. (2005). Biological considerations in geotechnical engineering. J. Geotech. Geoenviron. Engng 131, No. 10, 1222-1233.

Mitchell, J. K. \& Soga, K. (2005). Fundamentals of soil behavior, 3rd edn. Hoboken, NJ, USA: J. Wiley \& Sons.

Mortlock, R. A. \& Froelich, P. N. (1989). A simple method for the rapid determination of biogenic opal in pelagic marine sediments. Deep-Sea Res. 36, No. 9, 1415-1426.

Muththalib, A. \& Baudet, A. B. (2019). Effect of heavy metal contamination on the plasticity of kaolin-bentonite clay mixtures and an illite-smectite rich natural clay. In 7th International symposium on deformation characteristics of geomaterials (IS-Glasgow 2019) (eds A. Tarantino and E. Ibraim), E3S Web of Conferences vol. 92, article 10005. Les Ulis, France: EDP Sciences..

Paul, M. A. \& Barras, B. F. (1999). Role of organic material in the plasticity of Bothkennar clay. Géotechnique 49, No. 4, 529-535, https://doi.org/10.1680/geot.1999.49.4.529.

Petronio, B. M., Cardellicchio, N., Calace, N., Pietroletti, M., Pietrantonio, M. \& Caliandro, L. (2012). Spatial and temporal heavy metal concentration $(\mathrm{Cu}, \mathrm{Pb}, \mathrm{Zn}, \mathrm{Hg}, \mathrm{Fe}, \mathrm{Mn}, \mathrm{Hg})$ in sediments of the Mar Piccolo in Taranto (Ionian Sea, Italy). Water Air Soil Pollut. 223, No. 2, 863-875.

Pineda, J. A., Liu, X. F. \& Sloan, S. W. (2016). Effects of tube sampling in soft clay: a microstructural insight. Géotechnique 66, No. 12, 969-983, https://doi.org/10.1680/jgeot.15.P.217.

Rashid, M. A. \& Brown, J. D. (1975). Influence of marine organic compounds on the engineering properties of a remolded sediment. Engng Geol. 9, No. 2, 141-154.

Santamarina, J. C. Klein, K., Palomino, A. \& Guimaraes, M. S. (2002). Micro-scale aspects of chemical-mechanical coupling: interparticle forces and fabric. In Chemo-mechanical coupling in clays: from nanoscale to engineering applications (eds C. Di Maio, T. Hueckel and B. Loret), pp. 47-64. Rotterdam, the Netherlands: Balkema.

Schulz, H. D. \& Zabel, M. (2000). Marine geochemistry. Berlin, Germany: Springer.

Sollecito, F., Vitone, C., Miccoli, D., Plötze, M., Puzrin, A. M. \& Cotecchia, F. (2019a). Marine sediments from a contaminated site: geotechnical properties and chemo-mechanical coupling processes. Geosci. (Basel) 9, No. 8, 333, https://doi.org/10.3390/ geosciences 9080333 .

Sollecito, F., Cotecchia, F., Mali, M., Miccoli, D. \& Vitone, C. (2019b). Geo-chemo-mechanical characterization of a polluted marine basin. In 7th International symposium on deformation characteristics of geomaterials (IS-Glasgow 2019) (eds A. Tarantino and E. Ibraim), E3S Web of Conferences vol. 92, article 18001. Les Ulis, France: EDP Sciences.

Spagnoli, G., Fernández-Steeger, T., Feinendegen, M., Azzam, R. \& Stanjek, H. (2011). Influence of the dielectric constant, electrolyte concentration and $\mathrm{pH}$ of the pore fluids on the shear strength of monomineralic clays. Riv. Ital. di Geotec. 2011, No. 3, 11-24.

Sridharan, A. (2002). Engineering behaviour of clays: influence of mineralogy. In Chemo-mechanical coupling in clays: from nanoscale to engineering applications (eds C. Di Maio, 
T. Hueckel and B. Loret), pp. 3-28. Rotterdam, the Netherlands: Balkema.

Sridharan, A. \& Ventakappa Rao, G. (1973). Mechanisms controlling volume change of saturated clays and the role of the effective stress concept. Géotechnique 23, No. 3, 359-382, https://doi.org/ 10.1680/geot.1973.23.3.359.

Tanaka, H. (2003). Pore size distribution and hydraulic conductivity characteristics of marine clays. In Proceedings of the 2nd international symposium on contaminated sediments. Characterization, evaluation, mitigation/restoration, management strategy performance (eds H. Tremblay, J. Locat and R. Galvez-Cloutier), pp. 151-157. Québec City, Canada: Université Laval.

Tanaka, H. \& Locat, J. (1999). A microstructural investigation of Osaka Bay clay: the impact of microfossils on its mechanical behaviour. Can. Geotech. J. 36, No. 3, 493-508.

Taylor, D. W. (1948). Fundamentals of soil mechanics. New York, NY, USA: John Wiley \& Sons.

Terzaghi, K. (1923). Die berechnung der durchlassigkeitzifer des tones aus dem verlauf der hydrodynamischen spannungserscheinungen. In Mathematisch-naturwissenschaftliche, Klasse, pp. 125-138. Vienna, Austria: Akademie der Wissenschaften.

Todaro, F., Barjoveanu, G., De Gisi, S., Teodosiu, C. \& Notarnicola, M. (2021). Sustainability assessment of reactive capping alternatives for the remediation of contaminated marine sediments. J. Cleaner Prod. 286, 124946.

Varghese, R., Chandrakaran, S. \& Rangaswamy, K. (2019). Geotechnical behaviour of different organic matter on clayey soils. Geomech. Geoengng 16, No. 4, 288-297, https://doi.org/ 10.1080/17486025.2019.1670874.

Vitone, C., Sollecito, F., Todaro, F. \& Corbelli, V. (2020). Contaminated marine sites: geotechnical issues bridging the gap between characterisation and remedial strategies. Riv. Ital. di Geotec. 2020, No. 4, 41-62, https://doi.org/10.19199/2020.4. 0557-1405.041.

Zumsteg, R., Plötze, M. \& Puzrin, A. (2013). Reduction of the clogging potential of clays: new chemical applications and novel quantification approaches. Géotechnique 63, No. 4, 276-286, https://doi.org/10.1680/geot.SIP13.P.005. 